\title{
AN OUTLINE OF ECONOMIC IMPACTS OF MANAGEMENT OPTIONS FOR ŠUMAVA NATIONAL PARK
}

\author{
IAN DICKIE ${ }^{1}$, GUY WHITELEY ${ }^{1}$, PAVEL KINDLMANN ${ }^{2, *}$, \\ ZDENKA KĽENOVÁ ${ }^{2}$, and JAROMÍR BLÁHA ${ }^{3}$
}

\author{
${ }^{1}$ EFTEC, 73-75 Mortimer Street, London W+W 7SQ, United Kingdom \\ ${ }^{2}$ Global Change Research Centre AS CR, Department of Biodiversity Research, Na Sádkách 7, 37005 České Budějovice and Institute \\ for Environmental Studies, Faculty of Science, Charles University, Benátská 2, 12801 Prague 2, Czech Republic \\ ${ }^{3}$ Hnutí Duha - Friends of the Earth Czech Republic, Lublaňská 18, 12000 Prague 2, Czech Republic \\ *Corresponding author: pavel.kindlmann@centrum.cz
}

\section{ABSTRACT}

This analysis briefly compares the economic impacts of three potential future management scenarios for Šumava National Park (NP) in the Czech Republic: (1) continuation of current management, (2) the adoption of draft Bills that would declassify protected areas and enable developments (e.g. ski lift development) within some of the Park's most valuable habitats for wildlife, and (3) the adoption of proposals to expand the wilderness area in the Park's core with associated tourism opportunities.

The proposals in the draft Bills have the potential to generate employment through ski lift development, but much of this activity will use imported labour and/or be short-term (e.g. associated with construction work). The financial viability of this development is uncertain for a number of reasons, including: likely requirements to compensate for damage to protected habitats, reduced future snow cover due to climate change, and competition to attract sufficient visitors to use the ski lift. The economic impacts of the adoption of the draft Bills (and, to a lesser extent, of continuing with current management) would also include negative effects on current nature tourism activity and on its long-term potential to expand. Currently, and certainly if the proposed plans in the draft Bill are adopted, the value of the NP as an area of wilderness and high-quality ecosystems will be reduced. This would weaken one of its key selling points as a tourism and recreation destination. The opportunity for international branding of the national park based on these ecosystems would be diminished. This damage to ecosystems would go against the views of the $75 \%$ of the Czech population who agree that it is important to halt the loss of biodiversity because we have a moral obligation to look after nature.

Pro-wilderness development offers an alternative scenario. It would allow economic opportunities to be pursued to promote nature-based tourism at new locations and activities around an expanded non-intervention zone, while not undermining the ecological integrity of the NP. The Šumava NP is a unique area which supports a wide variety of habitats and species and has the potential to form one of the largest areas of natural forest and wetland habitat in Central Europe. This tourism offer is in keeping with visitor's preferences (identified in a 2010 survey), and can exploit global growth in ecotourism activity. The best access points to the Šumava NP's wilderness are currently regarded as being "full" in that further increases in visitors would damage the wilderness experience which draws visitors. Therefore, there is perceived to be demand for a larger number of carefully managed access points to a larger wilderness area.

To maximise the local economic benefits of this tourism development around the park, appropriate training for the local workforce is required. Local benefits could be enhanced through nature-based tourism development that is spread throughout the communities in and around the park. This would not conflict with the park's wild image that attracts visitors, and this visitor market could grow with support from expanded marketing activity. The potential local economic benefits from the pro-wilderness development option include: maintaining and expanding employment in management of the National Park's habitats, visitor facilities and access points; increased nature-based tourism trade in the villages within and surrounding the Park; increased opportunities to attract financing for local economic development (e.g. training and SME support for nature-based tourism), and for the Park's management, both internationally (e.g. from EU funding sources), and locally (e.g. through fees for visitors using specific facilities); a greater proportion of value-added in the tourism offer being generated within the local community, meaning more income can be retained locally and support greater indirect economic activity, and maintaining forestry employment.

Key aspects of this analysis are the way in which tourism potential at the Park is developed, and the extent of logging as a measure to manage bark beetle. Šumava NP borders the Bayerischer Wald NP in Germany, which has developed a successful nature-based tourism industry. This offers a proven model to pursue sustainable economic development under the pro-wilderness development scenario, and a unique opportunity for complementary promotion of the two parks branded as the "Wild Heart of Europe".

More specific predictions of economic and employment impacts will require a full economic study. However, this initial analysis indicates that the pro-wilderness scenario offers a more economically and environmentally sustainable development plan for Šumava NP than either the current situation or the plans proposed in draft Bills. It is recommended that proposals in draft Bills should not be pursued at least until a fuller economic evaluation of options has been undertaken.

Keywords: Šumava National Park, socio-economic analysis, Wild Heart of Europe

\section{Introduction}

Šumava National Park (NP) was established in 1991. Its status as an area of high conservation importance is reflected in several international designations: Šumava's peat bogs are designated Ramsar sites (which are wetlands of international importance); and the Šumava
NP is part of the EU's Natura 2000 network due to both Special Protected Area and Special Area of Conservation designations (under the Birds and Habitats Directives respectively).

Šumava harbours important populations of many species including capercaillie (Tetrao urogallus), Ural owl (Strix uralensis), three-toed woodpecker (Picoides tridac- 
Bark beetle (Ips typographus) is the main pest species in commercial forests of spruce trees. Bark beetles attack mature trees and infestation results in the death of the tree. Bark beetle outbreaks are a natural feature of Šumava, and the Park has experienced significant outbreaks of bark beetle in the recent past. This makes it a key issue in the management of the NP, and leading to a debate about the appropriate management of bark beetle. Spruce trees are an important habitat in the Park, supporting red list species.

The three scenarios considered in this study differ in their approaches to bark beetle management. This is a major reason why they involve different sizes and locations of non-intervention areas, and therefore of "core" conservation areas (described in Section 2.1 below). Broadly two management approaches are suggested in the management of bark beetle:

- Intervention - includes trap trees, insecticides and salvage cutting (Grodzki et al. 2006). This is practiced on the majority of Šumava NP, with appropriate intervention in perimeter areas.

- Non-intervention - no management intervention on forests affected by bark beetle. Practiced in non-intervention areas of Šumava NP (also with appropriate intervention in perimeter areas).

It is beyond the scope of this report to offer an in-depth assessment of these management practices, but key issues are that:

- Management "interventions" do not always appear to be effective - Grodzki et al. (2006) found no significant differences between tree mortality in intervention and non-intervention management areas and the outbreaks in both intervention and non-intervention areas ceased approximately at the same time.

- Bark beetle outbreaks are a natural phenomenon, but they have been exacerbated by the spruce monocultures that currently exist in the Park. ${ }^{1}$

- Non-intervention management results in a more varied vegetation structure and therefore has significant benefits for biodiversity and greater resilience in the longer term (Müller et al. 2008; Kindlmann et al. 2012; Bláha et al. 2013).

- Proponents of intervention may argue for "one-off" felling to achieve bark beetle management, but in practice this would be a regular cycle of intervention equating to a managed forest environment.

It is worth noting recent developments on bark beetle management in Austria, where a recent paper provides guidance on how to deal with bark beetles outbreaks in Austrian national parks and wilderness areas. ${ }^{2}$ The proposed management approach will not compromise the non-intervention philosophy in the core zone of these areas, while at the same time providing sufficient protection to surrounding landowners and their managed forests. It is based on a zonation model, which foresees a bark beetle control zone of varying width around the non-intervention zones of the protected areas. It now enjoys the broad support of Austrian conservationists and forest management authorities alike (WWF Austria, pers coms, Nov 2013).

Box 1 Bark beetle management.

tylus), lynx (Lynx lynx), moose (Alces alces), peregrine falcon (Falco peregrinus) and freshwater pearl mussel (Margaritifera margaritifera) (Bláha et al. 2013).

The management of Šumava NP is a politically sensitive issue, attempting to strike a balance between promoting local economic wellbeing and protecting the area's ecological importance. Reflecting the political uncertainties and complexities of the management of the area, Šumava NP has had nine directors in its 22 year history, in contrast to the Bavarian Forest NP (in the region adjacent to Šumava on the German side) which has had 3 directors in its 43 years. Recent debate surrounding the management of the NP, in which the international scientific community and NGOs discussed the future of the Šumava NP with the current NP director, local politicians, and developers, has attracted significant media interest in the Czech Republic. The NP has also attracted international attention criticising current management practices and plans for the future.

The Park's management is based on management zones with different levels of access and resource use, and allowing interventions against bark beetle (see Box 1). It is apparent that the scientific community support

1 Marie Fischborn, IUCN Global Protected Areas Programme Marie Fischborn, IUCN Global Protected Areas Programme, accessed 12/8/13: https://portals.iucn.org/blog/2012/08/09/sumava-national-park-to -beetle-or-not-to-beetle/

2 http://www.nationalparksaustria.at/fileadmin/pdf_s/NPA_News /Englisch_Bark_Beetle.pdf non-interventionist management of bark beetle ${ }^{3}$. However, intervention management practises bring revenue for the NP Authority in the form of timber, and create employment. These direct market returns can mean that intervention management practises are favoured by decision-makers. This view does not take into account the wider economic benefits that biodiversity can bring through indirect support for market activity (e.g. tourism), and non-market benefits (i.e. the value people place on maintaining a healthy ecosystem within the National Park).

The purpose of this report is to briefly compare the economic impacts value arising from three management scenarios for the Šumava NP: firstly if the current status of the park continues; secondly if the Bill drafted for the Czech parliament earlier this year is adopted, enabling declassification and development of areas of the Park; and thirdly if the management of the NP adopted a 'Pro-Wilderness' approach (see section Definition of the Scenarios for details).

The park is currently split into three zones: Zone I is the most valuable and strictly protected part of the NP (which should be equivalent to the core zone under Czech legislation), Zone II includes the natural ecosystems that in the past were variously influenced by human activities, and Zone III has areas which allow a wide variety of activities on them. More details on the zonation

3 E.g. as in the view of the Policy Committee of the Society for Conservation Biology, Europe Section, 2012, see also Box 1. 
and intervention strategies in the NP are contained in the sections below. The issue of the management of the NP is currently under discussion due to the drafting, earlier last year, of a Bill to the Czech Parliament that has proposed a change to the zonation of the NP. This is intended to promote interventionist bark beetle management and encourage economic development, but is seen by many conservation organisations as a threat to the habitats within it (see section Regulating Ecosystem Services).

This report does not undertake primary assessment of the ecological damage or benefits that will occur under any of the three scenarios. It instead relies on existing scientific and economic evidence from Šumava itself, evidence from a fact finding trip in July 2013 and comparable regions including the Bavarian Forest in Germany which borders the NP, to assess the economic potential of different development options.

\section{Scenarios}

This section outlines the alternative scenarios for management of Šmava NP, and the categories of economic impact that each one is subsequently assessed against.

\section{Definition of the Scenarios}

The three alternative future scenarios look at the short-medium term economic consequences (i.e. roughly up to 10 years ahead) of:

1. What is happening now and the prognosis for the park under current trends (current status).

2. If the Bills drafted for Parliament earlier this year were to pass and be implemented (Bill adoption).

3. If proposals supported by the scientific community were accepted and the area of non-intervention increased (pro-wilderness).

\section{Current Status}

This scenario assumes that current management approaches continue without significant change into the future. The current areas of zones, shown in Fig. 1, are maintained. As described in Introduction, Šumava NP has several designations as it is of international conservation importance for several species and habitats. However, the most ecologically valuable areas of habitat are highly fragmented: there are 135 Zone I segments in the Park. These are shown in Fig. 1.

Since the Šumava NP was established in 1991, zonation was used to define protection (Bláha et al. 2013). Zone I is the most strictly protected part of the national park. These are areas which are considered to be natural or semi-natural ecosystems of greatest conservation value. Zone II is managed actively to increase its ecological value, generally in preparation of some parts for inclusion in Zone I prior to 2030 (Křenová and Hruška 2012). Zone III areas are villages and areas of significant human

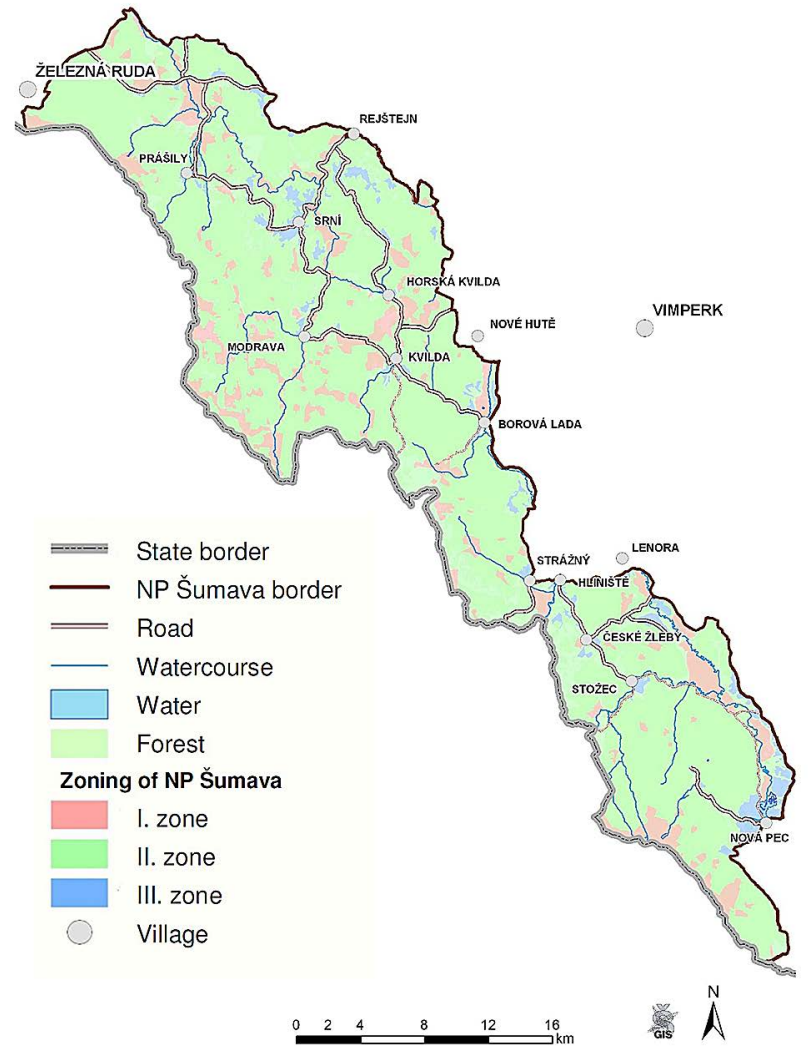

Fig. 1 Current zoning of Šumava NP.

impact. After the windstorm Kyrill in $2007^{4}$ the fragmented zonation was partly consolidated by NP management. The non-intervention regime was extended from Zone I to some parts of Zone II.

Under the current zoning, only $13 \%$ of land is classified as Zone I and the designation is split into 135 fragmented areas. This arrangement has been in place since 1995, when a change in leadership favoured active management of areas infested with bark beetle - an approach that has been criticised by a range of experts, including IUCN and the Ramsar Committee (Bláha et al. 2013). The current non-intervention area (Zone I plus part of Zone II with non-intervention against bark beetle from 2007) is much smaller than that proposed by scientists, based on GIS analyses of the actual extent of Natura 2000 habitats (52.2\% for Zone I, out of which $49.8 \%$ should be non-intervention - Bláha et al. 2013).

As shown in Table 1, compared to other national parks in this region of Europe, non-intervention core areas of Šmava NP form a much smaller proportion of the NP and are much more highly fragmented. ${ }^{5}$

As stated in the UK's Lawton Review ${ }^{6}$ on the management of sites designated for nature conservation, "species

4 A strong windstorm in 2007 that felled approx. 700,000 trees in Šumava, and as a result initiated last massive bark-beetle outbreak.

5 Fragmentation occurs where a contiguous habitat becomes broken up into smaller disconnected islands of the habitat.

6 Lawton et al. (2010) An Independent Review of England's wildlife and ecological network commission by the government chaired by Professor John Lawton. 
Table 1 National Parks in the region.

\begin{tabular}{|c|c|c|c|c|c|c|}
\hline Park & Country & $\begin{array}{c}\text { Date } \\
\text { established }\end{array}$ & Area (ha) & $\begin{array}{c}\text { IUCN } \\
\text { category }\end{array}$ & $\begin{array}{c}\text { Non-intervention } \\
\text { area }\end{array}$ & $\begin{array}{c}\text { Number of parts } \\
\text { of core zone }\end{array}$ \\
\hline Bayerischer Wald & Germany & 1970 & 24,217 & II. & $57.3 \%$ & 7 \\
\hline Bialowieski & Poland & 1947 & 10,517 & II. & $45 \%$ & 1 \\
\hline Kalkalpen & Austria & 1997 & 20,850 & II. & $89 \%$ & 1 \\
\hline Donau-Auen & Austria & 1996 & 9,300 & II. & $85 \%$ & 1 \\
\hline Berchtesgaden & Germany & 1978 & 20,800 & II. & $66.6 \%$ & 3 \\
\hline Triglav & Slovenia & 1961 & 88,000 & II./N. & $35.7 \%$ & 2 \\
\hline Tatra & Poland & 1954 & 21,164 & II. & $54 \%$ & 1 \\
\hline Krkonošský & Czech Republic & 1963 & 36,300 & V. & $12 \%$ & 6 \\
\hline Podyjí & Czech Republic & 1991 & 6,300 & II. & $35 \%$ & 1 \\
\hline Šumava & Czech Republic & 1991 & 69,030 & II. & $13 \%$ & 135 \\
\hline Bieszczady & Poland & 1973 & 29,202 & II. & $63 \%$ & 2 \\
\hline Hohe Tauern & Austria & 1981 & 185,600 & II. & $61.7 \%$ & 5 \\
\hline
\end{tabular}

Source: http://protectedplanet.net/, Křenová and Bláha, pers. comm. August 2013.

confined to small, single, or only a few sites, are unlikely to be adequately protected". There is a wide evidence base which shows that small areas offer less effective protection for species: ${ }^{7}$

- small areas support small populations, with more limited gene pools, therefore species could naturally fluctuate into extinction;

- lower diversity in species due to low habitat diversity in smaller areas;

- edge effects - the edge of protected areas are often affected by external environment pressures (pollution, noise, human interference); the smaller the protected area, the greater chance these external impacts will penetrate all of the area, therefore no area will stay free from impacts in the protected Zone;

- "Allee effects" - which mean that species do not breed successfully at low densities.

The fragmentation of habitat within the management zones in Sumava NP reduces the nature conservation benefits of the most highly protected areas - with related implications for ecotourism potential. In response to the current status of the NP, the European Commission have been in contact with the Czech Government to raise concerns about the current management of the NP, and its impact on Natura 2000 sites. $^{8}$ There are also clear recommendations from IUCN and the European Council to change the zonation in the current management strategy and implement a clear and long term strategy for management of Šumava NP.

7 MacArthur and Wilson (1967); Franklin (1980); Shaffer (1981); Gilpin (1986); Berger (1990); Abensperg-Traun and Smith (1999); Berger (1999); Pardini et al. (2005); Groom et al. (2006); Willi et al. (2006); Bulman et al. (2007); Trail et al. (2007); Harris and Pimm (2008).

8 Answer given by Mr Potočnik on behalf of the Commission (10 July 2012): http://www.europarl.europa.eu/sides/getAllAnswers.do?reference $=\mathrm{E}-2012-005294 \&$ language $=$ SK
In a visit in 2010 to evaluate Šumava for a European Diploma (a protected areas award from the European Council), the Council's representative Pierre Gallant stated that: "The Šumava NP forms with the neighbouring Bavarian Forest NP a unique forest Zone in the middle of Europe susceptible to host and demonstrate natural forest dynamics and ecosystem processes.... Recognizes however that the current local and national political climate in the ŠNP does not offer sufficient guarantee regarding the long term management and the preservation of the park and that some essential management instruments are missing."

This evaluation for the European Council recommended postponing the awarding of the Diploma to the Sumava NP until the following conditions were to be fulfilled: a new zonation plan/system, a 10 year management plan respecting recommendations of international experts (IUCN, Ramsar etc.), and guarantees of cooperation with the Bavarian Forest NP authority.

Under the current management regime Šumava National Park is not fulfilling its ecological potential.

\section{Draft Bill Adoption}

There are two drafts of the Bill recently developed for submission to the Czech Parliament: one by the Pilsen local government ${ }^{9}$ and one by the government (prepared by the Ministry of Environment). ${ }^{10}$

The most advanced one in terms of preparation is the Bill drafted by the Ministry of Environment (the current director of the Šumava NP was substantially involved in its preparation) and therefore we will use it in the following assessment. However, as these two proposals do not differ substantially in matters analyzed here, so conclusions and recommendations hold also for the second proposal.

9 http://www.psp.cz/sqw/historie.sqw?o=6\&T=435

$10 \mathrm{http}: / /$ www.psp.cz/sqw/historie.sqw? $=6 \& \mathrm{~T}=999$ 


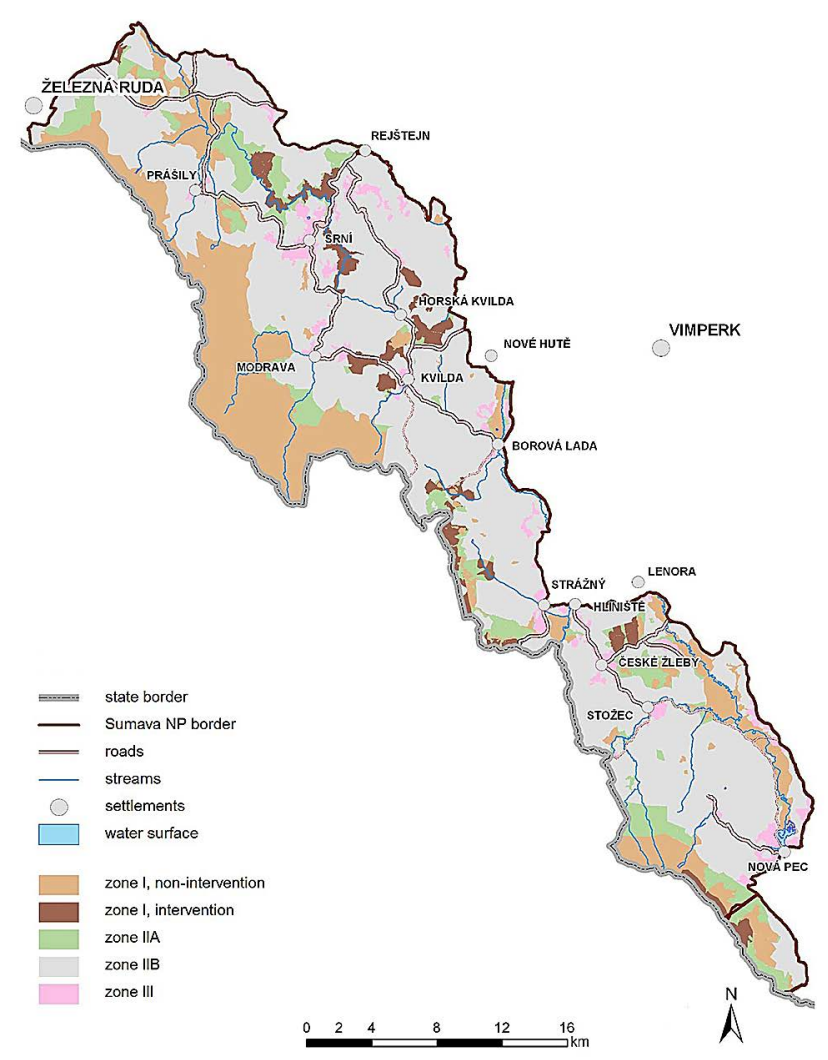

Fig. 2 Zoning under draft Bill (Ministry of Environment) proposals.

The plans in the Bills drafted for Parliament propose changes to the areas and definitions of the three types of Zone in the NP. Zone I is again comprised of those areas with significant biodiversity values. Zone II is comprised of those areas that have natural value, but are again compromised in some way by human activity. Zone II areas are split into Zone IIA and Zone IIB. Zone IIA areas are those that are suitable for ecological recovery within 15,30 or 45 years, but logging will be allowed in them within these timescales. Zones IIB are those areas permanently designated as "nature friendly management". Zone III are those areas that are mainly used for business, tourism, sport and recreation, and are also potential areas for development.

Zone I designation prohibits all intervention management activities. But according to Annex 4, Part A of the Bill exceptions to these rules exists in certain territories in the NP. The Bills nominally propose increasing the Zone I area to $26.53 \%$, but in practice it will comprise $22 \%$ non-intervention zones and $4 \%$ "intervention zones" in which felling will be allowed (meaning it is not actually a non-intervention zone). These proposals would increase the total size of Zone I areas and reduce fragmentation of the core areas from 135 segments to 37. However, the current non-intervention area of the NP will actually be reduced. These zones are shown in Fig. 2 .

A variety of management interventions are allowed in the Zone II and Zone III areas. Zone IIB designation allows significant interventions on the land, including timber production for the local population, clearing of brushwood, establishing tourist infrastructure. Zone III

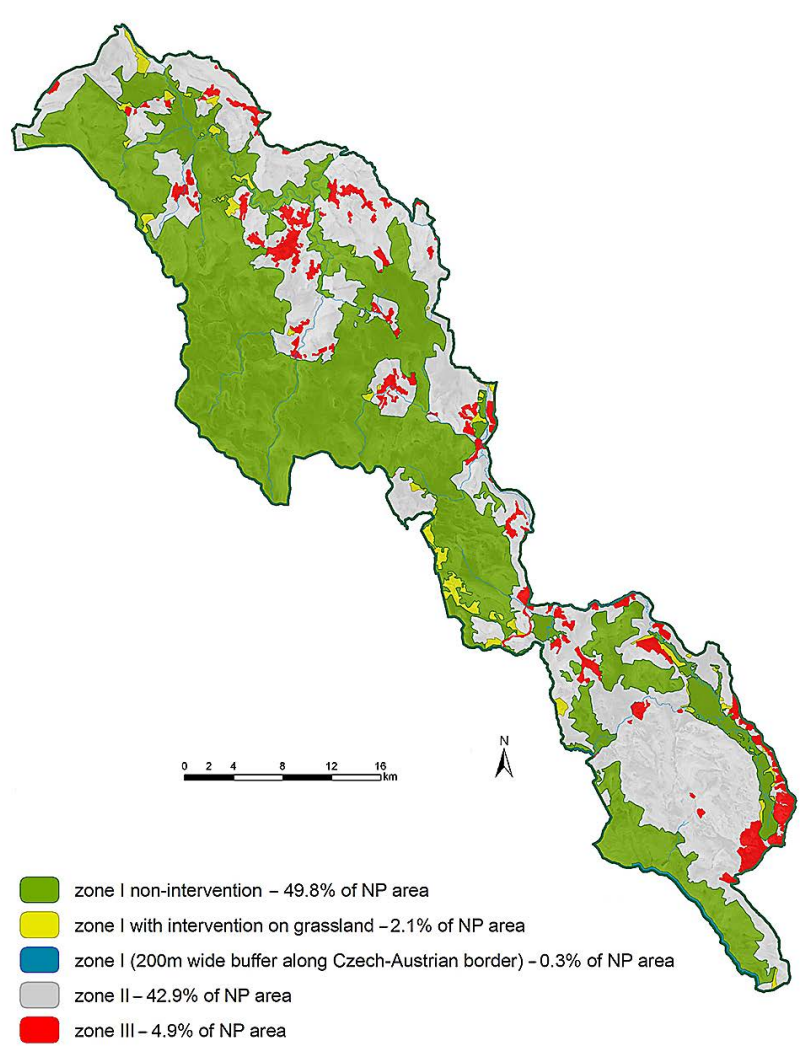

Fig. 3 Zoning under increase in non-intervention area proposal.

allows timber management interventions and economic development opportunities. This includes a proposed ski lift and run. Zone IIA will be $8.49 \%$, Zone IIB will be $59.87 \%$, Zone III $5.12 \%$.

Under drafts of the Bill, a significant part of the existing core areas will be de-classified from their present strictly protected status and logged, in many cases based on arguments for interventionist bark beetle management. Extensive areas of the Park would be opened up to a variety of high impact activities, such as building and infrastructure development. These are proposed to include development of ski-lifts, and an expansion of the touristic road network, which may affect survival of some species (e.g. capercaillie).

It is concluded that under the drafted Bills habitats in Sumava NP will remain fragmented, although fragmentation will be reduced, and zone 1 areas will cover a lower proportion (only $44 \%$ ) of the highest-value habitats. Combined with increased development pressures, this means the ecological value of the NP will fall.

\section{Increase of the Non-intervention Area ("Pro-Wilderness")}

The natural ecosystem (pro-wilderness) scenario is based on an ecological optimum size of Zone I, as defined in Bláha et al. (2013). This was calculated by defining a merged area using a GIS-based mapping of the most important features characterising the Natura 2000 status of the NP. The proposal is that $52.2 \%$ of the Šumava national park is defined as Zone I of which $49.8 \%$ is defined as non-intervention. These zones are shown in Fig. 3. 


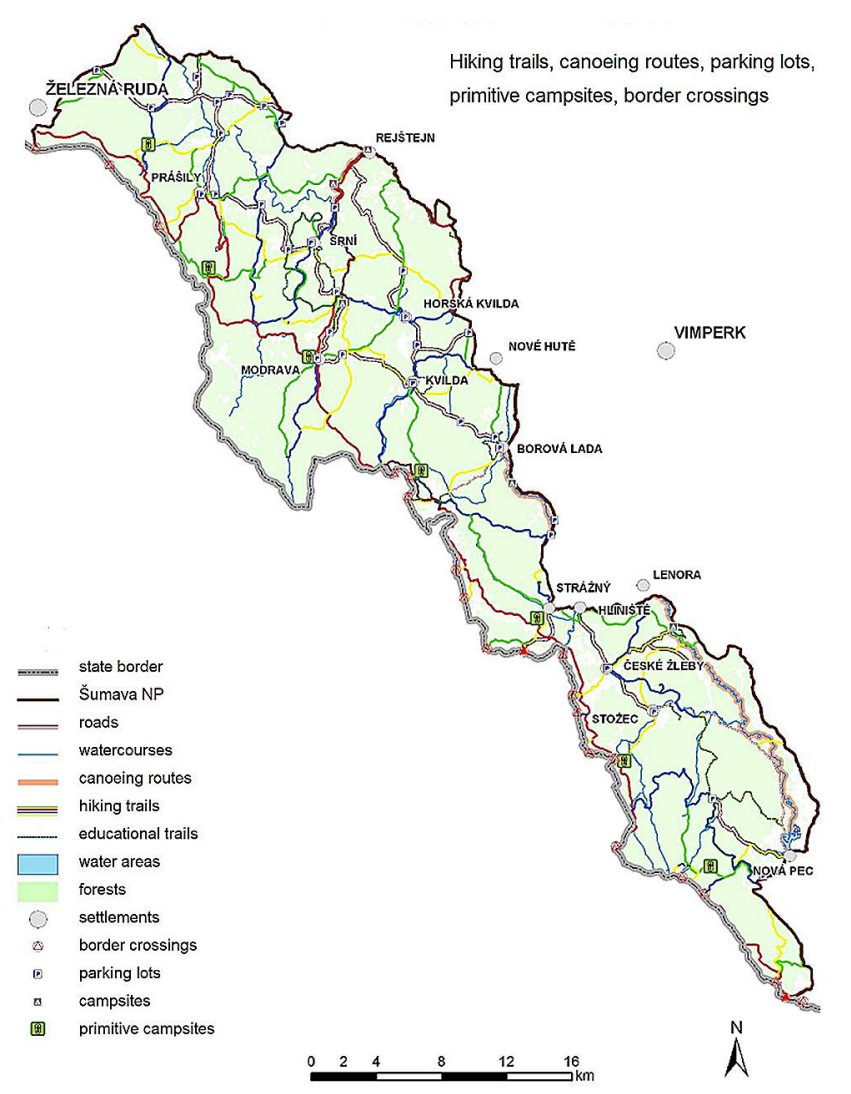

Fig. 4a Current hiking and canoeing routes in Šumava NP.

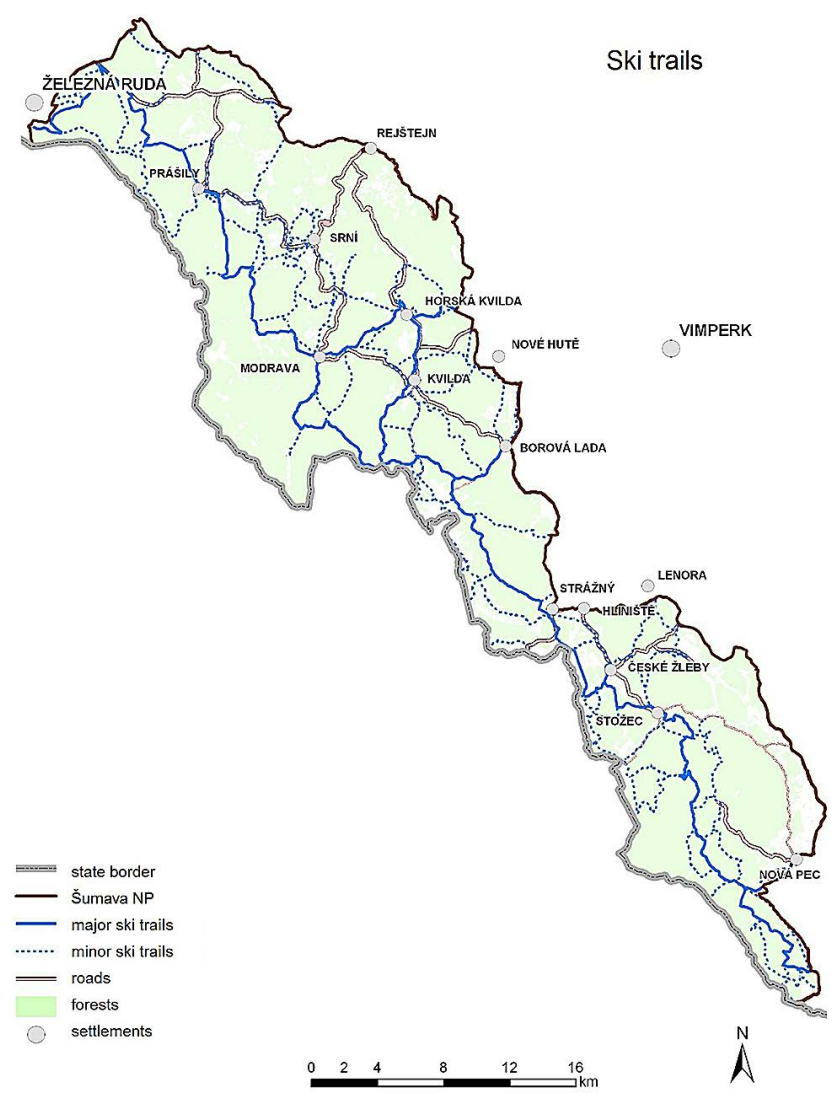

Fig. 4c Current maintained cross country ski routes in Šumava NP.

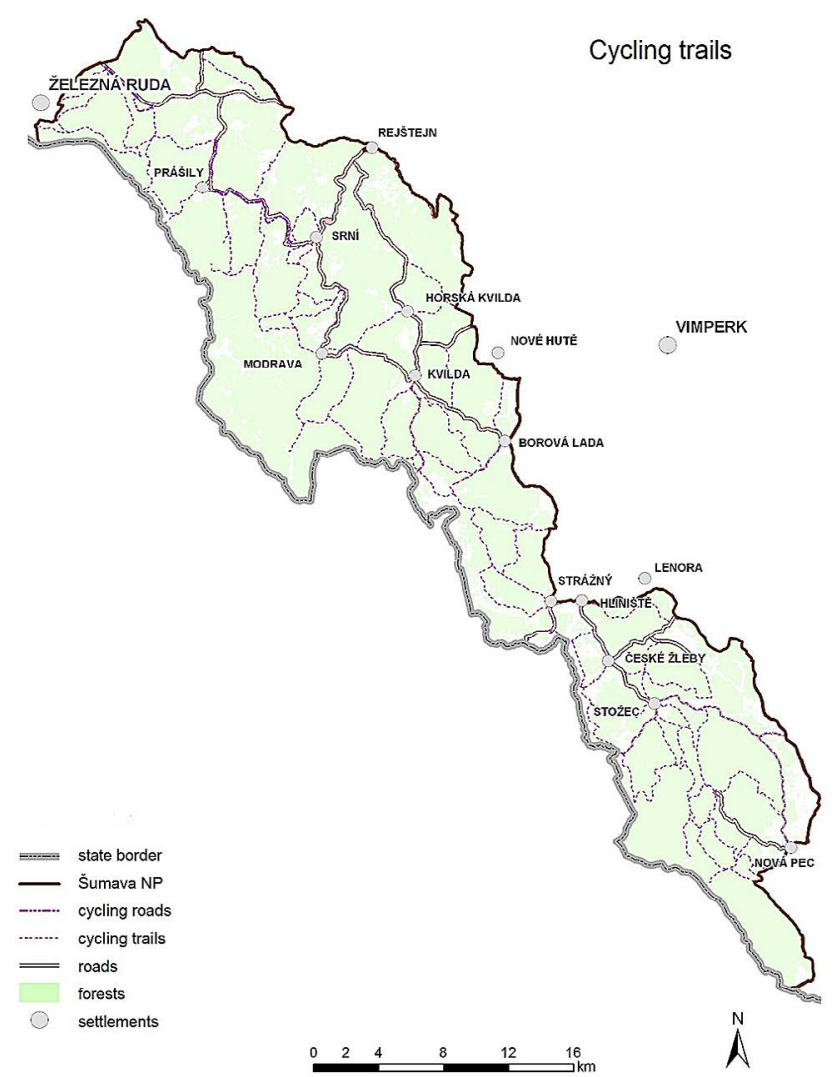

Fig. 4b Current cycling routes in Šumava NP.

This pro-wilderness scenario also involves investment in the promotion of nature-based tourism (with marketing based on the "wilderness experience"), and in the local economy's ability and infrastructure for supplying these services for this market. There are numerous locations and opportunities to invest in small-scale infrastructure and low-impact access to Zone II areas. These developments would be based around current paths with the NP, as shown in Fig. $4 \mathrm{a}-\mathrm{c}$. They would not take place in locations where they would damage the ecological value of the NP (e.g. they would not increase fragmentation of habitats).

The zoning under this proposal, including the larger non-intervention area, is also intended to provide a more coherent large scale approach to bark beetle management. There would be a defined NP perimeter beyond which interventionist management, including felling to control the spread of bark beetle, could be employed.

It is concluded that under pro-wilderness proposals the ecological integrity of the NP will be assured and improved, with accompanying sustainable economic potential.

\section{Categories of Assessment}

The three management scenarios for the Šumava National Park will be assessed against the following catego- 
Table 2 Summary of scenarios.

\begin{tabular}{|l|l|c|c|c|c|}
\hline \multicolumn{1}{|c|}{ Scenario } & \multicolumn{1}{|c|}{ Non-intervention } & Zone I & Zone II & Zone III & \multicolumn{1}{c|}{ Additional } \\
\hline Current status & $\begin{array}{l}30 \% \\
\text { Long term goal: } \\
\text { at least } 50 \% \text { by } 2030\end{array}$ & $13 \%$ & $82 \%$ & $5 \%$ & High fragmentation. \\
\hline $\begin{array}{l}\text { Draft Bill } \\
\text { adoption }\end{array}$ & $\begin{array}{l}22 \% \\
\text { Phased adoption of } \\
\text { non-intervention (over 15, } \\
30 \& 45 \text { yrs), up to 35\% after } 45 \text { yrs }\end{array}$ & $27 \%$ & IIA: $8 \%$ & IIB: $60 \%$ & $\begin{array}{l}\text { Declassification and logging of existing core } \\
\text { areas. Particularly consolidation of fragmented } \\
\text { areas, re-labelled as core. Increased development } \\
\text { of infrastructure and building within the NP. }\end{array}$ \\
\hline $\begin{array}{l}\text { Pro-natural } \\
\text { ecosystem } \\
\text { ("wilderness") }\end{array}$ & $50 \%$ & $\begin{array}{l}52 \% \\
\text { (including } \\
\text { buffer zone } \\
0.3 \%)\end{array}$ & $42 \%$ & $\begin{array}{l}\text { Large un-fragmented non-intervention zones } \\
\text { to support habitats and species within them, } \\
\text { and provide large scale plan for bark beetle } \\
\text { management. Expansion of nature tourism and } \\
\text { related activities. }\end{array}$ \\
\hline
\end{tabular}

ries, which are chosen to represent the main elements to the total economic value from future management:

- Tourism - The potential for the development of tourism activities in Šumava NP.

- Regulating Ecosystem Services - Ecosystem services are those benefits that functioning ecosystems provide human populations. The key regulating services to be considered are water cycle regulation, including flood alleviation, and climate regulation through carbon stored in ecosystems.

- Non-use and Existence Values and Reputation A national park and the species within in it are not only valued by tourists, locals, loggers or those who use the park directly. The general population also value and have an interest in nature in situ, even if they do not directly benefit from it in any tangible sense. These are known as "non-use" values and include the values that people put on knowing that species exist ("existence values"). These non-use values can in part determine the reputation of the NP.

- Local Economic Impacts and Employment - The impacts on the extent and viability of economic activity in and around the national park, and the employment opportunities provided by the NP including those in forestry activities.

- Financial Viability - The level of revenue generation and the ability to generate and sustain sufficient funds to enable the NP to be managed effectively.

One assessment category looks specifically at regulating ecosystem services. It is recognised that ecosystem services are also part of other categories. These include revenues from provisioning services, and depending on the ecosystem services classification adopted, "Tourism" and "Non-use values" can be regarded as ecosystem services. However, the focus of this report is on economic impacts arising from management, and is not a full ecosystem services assessment of the NP. Therefore these other (non-regulating) ecosystem services are not described using ecosystem services terms in this report.

Valuations of the ecosystem services from Šumava NP have been estimated by a team in the Czech Republic
(Frelichová et al. 2013 - see Annex 1 for more details). In their study, the team took peer reviewed valuations of ecosystem types close to those occurring in the Czech Republic. These per hectare values were multiplied by area of ecosystems in Šumava and aggregated to give total values. The Šumava National Park was estimated to currently support values on average of $€ 16,789 / \mathrm{ha} / \mathrm{yr}$ with a total value of $€ 1.6$ billion/yr.

This is a preliminary result from the study and a number of limitations exist in the methods used. The total value it identifies can be considered to provide an approximate "order of magnitude" estimate of the value of ecosystem services from Šumava NP. It suggests the value of these services is very significant. However, the methods involved, being based on transfers from similar areas rather than direct observations at the site, cannot generally be used to evaluate the changes in ecosystem services under the three scenarios.

\section{Current Status}

This scenario sets out the current economic circumstances of the NP.

\section{Tourism}

Approximately 2 million tourists visit the Šumava NP every year, ${ }^{11}$ the vast majority of which are from within the Czech Republic (Gorner and Čihař 2013).

A range of nature and landscape based tourism activities occur in the NP. Mountain biking is the predominant activity undertaken by visitors. The paved roads, a relic of the military past and forest management of the area, result in particularly accessible cycling routes. The success of biking in the national park and the extensive network of paved roads has potentially come at the expense of visitors intending a "wild" hiking experience. Paved roads have limited appeal to those hikers seeking wilderness and do not offer an attractive walking surface for wild hiking. Other activities that also take place here have de-

$11 \mathrm{http}: / /$ www.sumava.com/rec_park_about.php?l=en 
veloped to different extents; these include: cross-country skiing; hunting; fishing; wildlife watching; snow walking; canoeing; bivouacking.

The information available suggests that tourism is a vital contributor, albeit seasonal, to the local economy in and around the Šumava NP. A survey carried out by the local Regional Development Agency in 2007 found that tourism and related sectors are responsible for 30\% to $50 \%$ of all jobs during the holiday season (Picek et al. 2007). Křenová and Kiener (2012) also report that tourism in the Šumava NP is important to the local economy.

Šumava NP is marketed as a tourism destination, but it is unclear as to the extent of that marketing material utilises the NP's characteristics, including its wilderness area, as a selling point. In $2009,68 \%$ respondents to a visitor survey said that the existence of the NP designation was important to their decision to visit Šumava (Bláha 2012).

The Regional Development Agency of Šumava recognises the region represents an area substantially untouched by development and that this is a large attraction for tourists. It is also stated that visitors come to Šumava because of hiking and sports, relaxation, "nature and landscape beauties" and "clean environment and calm and quiet places" (Picek et al. 2007).

Assuming it is reasonable to transfer visitor spending data from the Bavarian Forest NP study (Nationalparkverwaltung Bayerischer Wald 2010) ${ }^{12}$ to Šumava, the approximately 2 million visitors to Šumava NP each year bring an estimated $€ 67.6$ million (2013 values) of spending. Daily spending rates have been adjusted from Germany to the Czech Republic by the Purchasing Power Parity method for this calculation. The local impact of this spending will be reduced due to leakage for government taxes, but increased by local multiplier effects (which depend on the strength of supply chains in the local area).

\section{Regulating Ecosystem Services}

The habitats that Šumava NP supports provide a number of "regulating" ecosystem services to the Czech public. Whilst a more in-depth valuation of the ecosystem services in Šumava NP has yet to be undertaken, it is possible to look at the benefits provided by Natura 2000 sites across Europe to estimate the ecosystem services potentially provided by the Šumava NP.

The Natura 2000 network was established under the 1992 Habitats Directive to recognise Sites of Community Importance (Bláha et al. 2013). Natura 2000 sites provide significant ecosystem services. Šumava NP is an import-

$1246 \%$ visitors have a high national park affinity and spend $€ 10.53$ if a day trip ( $29 \%$ visitors) and $€ 45.83$ if staying overnight (71\% visitors). $54 \%$ visitors have a low national park affinity and spend $€ 8.60$ if a day trip (37\% visitors) and $€ 45.82$ if staying overnight (63\% visitors). All values contained in report have been inflated to 2013 values and adjusted for Czech Purchasing Power Parity (PPP) which adjusts exchange rates for the relative costs of living in the countries concerned. ant site in the Natura 2000 network due to its large size and significant number of features of conservation importance.

Results from a recent assessment from the overall Natura 2000 network in a recent study (European Commission, 2013), included:

- Carbon Storage - those benefits that come from storage of carbon in the Natura 2000 network is between $€ 600$ and $€ 1,130$ billion (stock value).

- Natural Hazards - Natura 2000 can provide mitigation benefits against natural hazards. At one site in Belgium the flood protection provided by a river landscape restoration range between $€ 640,000$ and $€ 1,650,000$ per annum.

- Water Provision - Nature provides water purification and provisioning services. The annual benefits from water purification is between $€ 7$ and $€ 16$ million per city and water provisioning is between $€ 12$ and $€ 91$ million per city.

- Cost benefit ratio - Benefits were seven times greater than costs across 300 Natura sites in Scotland, this finding was repeated in France. In Finland, a study of the benefits associated with protected areas found that $€ 1$ investment generated $€ 20$ of returns.

These data suggest that regulating ecosystem services from Šumava NP are of significant value. It is also noteworthy that in the study of Šumava by Vačkár et al. (op. cit.) the ecosystem service values generally, and for regulating services, were higher in the Park's non-intervention areas.

\section{Non-use and Existence Values, and Reputation}

Habitat and species conservation is an issue of global concern and where biodiversity is threatened, there is evidence that large numbers of people express their support for a positive outcomes for nature. In several recent petitions, a global audience have put their names to supporting conservation issues illustrating that millions of people hold existence values for conserving nature. ${ }^{13}$

If these petitions have no impact on the petitioned action, then considerable numbers of people will have reduced welfare as a result of the decisions by the government/organisation who are responsible for managing that environment. It is sometimes possible to quantify the value that individuals give to the existence of habitats and species (existence values). Environmental valuation research using stated preference techniques has demonstrated that these values exist and can be significant. A number of examples from the economics and conservation academic literature are presented in Annex 2.

The high biodiversity value and unique landscape and wilderness attributes of Šumava NP means it is highly likely that the Czech population, citizens across Central Europe, and globally, hold significant values for its exis-

13 http://www.avaaz.org/en/index.php 
tence. This is supported by an opinion poll ${ }^{14}$ that showed a majority of the Czech population disagreed with damaging developments within the NP (see section Local Economic Activity and Employment).

Any damaging impacts on nature will be perceived negatively by this population and therefore damage the NP's reputation.

We can conclude from the existence of numerous petition websites and non-use valuation studies that is likely that significant international and national values are held for the existence of Šumava NP as a site of conservation importance. The current condition and management of the park threatens this value. ${ }^{15}$

We suggest that the continuation of current management would result in reputational damage for the National Park and safeguarding of the Czech natural heritage generally. This could result in loss of investment, and of nature- and landscape-based tourism.

\section{Local Economic Activity and Employment}

Approximately 950 people live in six villages inside the NP (Gorner et al. 2012). A further 1,180 people live in three villages on the border of NP. Altogether 2,130 people live in these villages in or on the border of the NP. In the area surrounding the Park there are 16 villages whose administrative boundaries partly overlap with the Park; they have approximately 15,000 residents. The population density of the area is three times lower than the national average (Picek et al. 2007). It has not been possible to conduct a detailed study on the local economy of the Šumava region due to limited information. For this reason we focus on job availability to those who live within the NP's borders.

In 2012 the national park employed 267 people (Šumava NP Yearly Report $\left.{ }^{16}\right)$. About 180 of these are employed in the department of ecosystem management of which 120 are foresters (Šumava NP Annual Report 2012). Unemployment rates inside the villages in the national park have ranged from $7.5 \%$ in June 2011, to $11.6 \%$ in December 2011. ${ }^{17}$ In absolute terms this amounts to 40 people in June and 62 in December. The unemployed are categorised to be former forest workers, who are generally older and have lower levels of education.

Aside from the seasonality of the work and the low educational levels within the work force, a key driver of job losses and unemployment in the region is the public procurement processes of the national park. The NP opens up forest management contracts to formal tenders $^{18}$ on a national and international basis. This has resulted in non-local foresters undertaking work in the

14 Factum Invenio 2011, available at: http://www.hnutiduha.cz/uploads /media/np_sumava_verejne_mineni.pdf

15 Report on the Trip to Šumava NP, Czech Republic, Policy Committee of the Society for Conservation Biology, Europe Section (2012).

16 http://www.npsumava.cz/gallery/23/7186-vz12_blok.pdf

17 http://portal.mpsv.cz/sz/stat/nz/uzem/

$18 \mathrm{http} / /$ www.npsumava.cz/cz/1525/sekce/lesis---prihlaseni-minitendry/; http://www.npsumava.cz/gallery/10/3118-sbornik4_lokalnirozvoj.pdf national park, while local foresters are unemployed. As well as underemployment of the local workforce, there is evidence of capacity in guest houses, hotels and other accommodation not being fully utilised. This means that greater numbers of visitors could be accommodated in the local area within current facilities.

While employment is a concern for the local area, the unemployment rate is relatively low, and the rate of unemployment in the region, and in the NP, is below the national average. This is attributed to the employment opportunities offered by nature-based tourism and management of the Park.

Comparing the key activities of forestry and nature-based tourism, the high imported element of forestry labour means that tourism activity related to the pro-wilderness alternative is likely to have greater value-added within the local economy. This will result in a greater proportion of income remaining within the local economy, and as a result higher tax revenues to local Government.

\section{Financial Viability}

The NP authority is mainly financed through the Ministry of the Environment (approx. €9 million), and the selling of wood (€6 million gross revenue) (Šumava NP Annual Report 2012). It does not appear that European funding contributes a significant amount towards the management of the National Park. Funding of the NP supports the substantial nature-based tourism spending that occurs in the local area (see section Tourism).

Czech law states that the forests in the NP are not to be used for profit (Act No. 114/1992 Coll.). Despite this trees in the National Park can be logged and sold for three reasons 1) bark beetle infestations (in Zone II and Zone III), 2) wind damages (extracting wind fallen timber), and 3) forest cultivation (Zones II and Zones III). The current scenario would maintain the current levels of funding (from timber) for the National Park, but would be likely to inhibit potential revenue from expanded nature-tourism activity.

\section{Draft Bill Adoption}

\section{Tourism}

Under this option, increased development of tourism infrastructure aims to encourage more people to the area of Šumava. A ski-lift in Nová Pec is a key aspect of the proposed plans. This is discussed below. An increased number of paved trails is also proposed that would increase the capacity for cyclists in the region. Whether this capacity will be filled depends on the nature of the demand. It is not clear if the demand exists in the Czech Republic to utilise the proposed infrastructure. There is a high risk that this development will undermine the reason why the visitors come to Šumava: near pristine ecosystems. 
As shown by the nature of the tourism offer and the attraction to visitors to NP status, tourism in Šumava is inexorably tied to the natural and wild landscape the national park provides. Preliminary assessments suggest that if the draft Bills proposals are adopted then habitats for crucial species will be damaged, as demonstrated in the letters of protests and opinion poll related to the drafted Bills. The survey ${ }^{19}$ suggested that degradation of habitats and ecosystems are likely to undermine the appeal of the national park to visitors. So this damage would be expected to significantly reduce numbers of visitors attracted - and related local spending and economic activity - by nature-based activities.

A detailed assessment is required comparing the potential local economic benefits of the proposed development to the potential local economic losses through damage to current nature-based tourism activities.

\section{Ski-lift Development}

The ski lift proposals need to be profitable to attract investment and sustain the claimed socio-economic impacts, such as job creation, in Nová Pec (in or near the east part of NP). The proposals claim to be potentially profitable based on attracting 130,000 users of the lift each year, made up of all of the 70,000 Czech users of the Hochficht (ski area in Austria) who currently enter it by road, and 60,000 new users attracted by the lift. Each user would pay $€ 35$ per day to use the lift and the Austrian ski area. One key benefit of downhill ski tourism is that it supports economic activity in the winter season.

There are uncertainties in the financial viability of the proposed ski-lift. The following analysis is based on an outline budget which has been made available (details available on request) with a project cost of CZK 250 million $(€ 9.6 \mathrm{~m})$ and projected profits of CZK 17 million $(€ 0.66 \mathrm{~m})$. This is a relatively low rate of profit $(7 \%)$, which makes the project's commercial viability sensitive to assumptions used in the business case or other factors:

- It is not obvious why all the 70,000 who currently access the Hochficht by car would use the Nová Pec lift. For a significant proportion of these visitors (depending on where they come from), driving to Austria could still be a more convenient option.

- A factor in the use of the Nová Pec lift is the influence of climate change. Being at a relatively low altitude, the season of operation of the lift is vulnerable to a reduction in the length of snow cover. Any reduction would reduce operating times, and therefore revenues and profits. Alternatively providing artificial snow would increase capital and operating costs.

- In trying to attract 60,000 new users per year, the site would be in competition with other ski locations. Other skiing resorts in the Czech Republic are availa-

19 Source: Šumava NP Visitors Questionnaire http://www.hnutiduha.cz /sites/default/files/publikace/2013/vystupy_anketa_sumava_2011.pdf; http://www.hnutiduha.cz/sites/default/files/publikace/typo3/Vystupy _anketa_sumava_2010.pdf ble, and not believed to be used at maximum capacity. If only 40,000 new visitors per year were attracted, the ski lift's operation would only approximately breakeven, meaning it would be unlikely to attract investment.

- It is unclear if the project costs include the costs of financing the investment. Whilst this may be less relevant for private equity investors, there is an expectation that the investments would be supported by public money (e.g. EU grants). In this case, the costs of financing the project are relevant given the severe budget constraints in Europe. Alternatively they can be regarded as reflecting the opportunity costs of investing in the ski lift rather than alternative investments (e.g. in the environment or education). Assuming grants are made worth $50 \%$ of the total costs, and are repaid over 15 years at a $\%$ (public sector) interest rate, the interests costs are CZK 30 million $(€ 1.1 \mathrm{~m})$. At higher commercial interest rates, the interest costs are higher.

- Finally, building the ski lift in a Natura 2000 site will mean compensation is required. If feasible, the potential costs of this are calculated (see below) at 20 million CZK per km², or 35 million CZK ( $€ 1.35$ million) in total.

It is clear from these issues that the financial viability of the ski lift proposal is uncertain, and requires detailed investigation and modelling. Allowing for the costs of financing the public grants for $50 \%$ of the project, or for the costs of habitat compensation, each give the project an expected loss of $€ 0.5 \mathrm{~m}$. Including both of these factors and allowing for a slightly lower number of new visitors (of 50,000 per year) gives the project a loss of approximately $€ 2 \mathrm{~m}$.

\section{Compensation}

The ski lift proposal would utilise land currently designated as a Natura 2000 site, and would negatively affect 50 protected species. ${ }^{20}$ If a plan or project having a significant impact on a Natura 2000 site is authorised, compensatory measures are compulsory, ${ }^{21}$ and it would be illegal to de-designate the site for economic purposes. Therefore, if the ski lift went ahead it would be required to compensate for damage to biodiversity, in line with Habitats Directive legislation. It is uncertain whether suitable areas for compensation exist, as they would need to be outside the Natura 2000 designations (as areas designated should already be managed to maximise biodiversity values). Here we assume that compensation is feasible, and calculate the potential costs of this, which should be included in the project costs.

\footnotetext{
20 http://portal.mpsv.cz/sz/stat/nz/uzem/

21 Source: page iv, DG Internal Policies (2009)

http://www.europarl.europa.eu/document/activities/cont/200910 /20091013ATT62399/20091013ATT62399EN.pdf
} 
The proposed ski lift would be approximately $2.5 \mathrm{~km}$ long. Logging to create space for the lift, and disturbance from the lift to surrounding habitat, is estimated to impact an area approximately $600 \mathrm{~m}$ wide. The total area impacted is therefore $2.5 \times 0.6 \mathrm{~km}=1.5 \mathrm{~km}^{2}$. It is noted that under some proposals there is also a proposed ski run, and this could further increase the width of habitat impacted. Therefore, this area estimate is conservative.

Compensation for this impact would require creation of high biodiversity value undisturbed forest. The costs of this are estimated based on the following costs:

- land purchase cost of approximately 2.4 million CZK per $\mathrm{km}^{2}$ (conservative estimate of the average cost of land ${ }^{22}$ ). Although land purchase may not be essential to undertake compensation, it is included in the costs to reflect the opportunity costs of the change in land use; - approximately 7.76 million of CZK per $\mathrm{km}^{2}$ for habitat creation of coniferous forest;

- management costs estimated at 0.5 million CZK per $\mathrm{km}^{2}$, which over 50 years discounted at $3 \%$ have a present value of approximately 13.25 million CZK per $\mathrm{km}^{2}$.

This gives a cost of 20.25 million CZK per $\mathrm{km}^{2}$. For the $1.5 \mathrm{~km}^{2}$ of total area impacted, the total costs are estimated at 35 million CZK, or $€ 1.35$ million.

\section{Regulating Ecosystem Services}

As stated above, contiguity of habitats is essential for nature conservation and functioning ecosystems. With increased development and access breaking undisturbed habitats, ecosystems are likely to have reduced functionality and therefore ecosystem services are reduced.

The ecosystem dynamics of Šumava are complex and difficult to model. The damage to habitats and increased intervention management regime undertaken in the NP are likely to reduce the value of these services, compared to the current management scenario. For example, greater use of intervention forest management is likely to reduce carbon being stored into the soil, and reduce regulation of water runoff.

The significance of these changes cannot be quantified without detailed analysis and/or modelling of the Šumava landscape. The drafted Bills, by damaging the integrity of ecosystems in the NP, put at risk the significant value of the ecosystem services provided by the NP ( $€ 1.6$ billion/yr, as described in section Categories of Assessment and Annex 1).

\section{Non-use and Existence Values, and Reputation}

In 2010 the Strategic Framework for Sustainable Development in the Czech Republic was issued (Ministry of the Environment of the Czech Republic, 201023). Priority 4.1 of this framework refers to landscape conservation as

22 http://www.bioreality.cz/data/1_251_cenovy-vestnik2013-c-14.pdf 23 http://www.mzp.cz/en/czech_republic_strategy_sd a pre-requisite for biodiversity conservation. Objective 2 of this priority states:

"In order to achieve the objective, there will be measures aimed at promoting preferential construction within or with links to existing settlements (but not at the expense of green residential areas)....minimizing ecosystem fragmentation (especially in cases where the construction of infrastructure and settlements gradually results in the separation of entire landscape and orographic units)".

Objective 3 states: "The protection and improvement of the condition of biotopes should be pursued through strict protection of surviving sites with natural communities (peat bogs, wetlands, primeval forests, etc.) and sound land management and use that takes account of the needs of specially protected and endangered species and specific communities."

The drafted Bills violate the spirit, if not also the wording, of this Sustainable Development framework, as it will result in deterioration in the condition of biotopes in the national park, and threaten the conservation of species. It is also suggested that the Bills violate the Habitats and Birds Directive ${ }^{24,25}$ by:

- downgrading important habitat from Zone I-II to Zone III to allow for construction work;

- reducing the core zones from their current size;

- establishing roads which will harm species and habitats.

The legal outcomes of these breaches are uncertain, but the conflicts they reflect between the drafted Bills and sustainable development and biological objectives do not enhance Šumava NP's brand with national, European or global communities, including amongst potential tourist visitors.

The current and future status of Šumava NP has already generated significant media interest and protests, demonstrating significant non-use values. The correspondence below has been directed at the government in response to the drafted Bills:

- In a letter to Ms Kateřina Sequensová, Czech Republic's ambassador to Switzerland, Nikita Lopoukhine Chair of the World Commission on Protected Areas (February 2012) expressed concern that the Bills will allow logging on two-thirds of the national park, and undermine the ecological processes and ecosystem services that park provides. The letter also states that non-intervention is the best management strategy for the park, and that the drafted Bills will go against the principles of the Convention on Biological Diversity.

- In a letter to Jiří Mánek, Director of Šumava NP, Andrej Sovinc, Regional Vice Chair for Pan Europe IUCN World Commission on Protected Areas and Hans Friederich, Regional Director IUCN Regional Office

24 92/43/ EEC and 2009/147/EC

25 Hnutí Duha - FoE Czech Republic Complaint to Commission. 
for Europe stated that Šumava NP would no longer be able to retain an IUCN Category II status under the management proposal contained in the Bills. Šumava would lose the ability to call itselfa "NP" internationally.

- A Resolution concerning the preservation of Šumava NP from the Society of Conservation Biology, Europe Section, stated that the drafted Bills would "compromise the area's biodiversity".

- An open petition letter has been signed by directors of 72 conservation organisations, research institutes and national parks, states that the plans contained in the Bills would damage the ecology of Šumava and calls for previous plans for an expanded non-intervention core zone to be reinstated.

- The European Commission in August 2013 published guidelines on management of wild and wilderness areas in the Natura 2000 network, giving for the first time recognition to the status and thus importance of non-intervention as a concept of ecological value for implementation. ${ }^{26}$

If one of the Bills is passed, it is likely that media interest and protests will increase. It is worth noting that two of the petitions which are discussed in section Non-use and Existence Values, and Reputation, which attracted in total 1.5 million signatories, relate to infrastructure being built across sensitive habitats. The Bills drafted for the Czech Parliament propose similar developments, albeit on a smaller scale.

Under the drafted Bills, developments would result in a reduction of non-use values due to damage to habitats are a result of ski infrastructure construction and increased intrusion to wilderness areas from mountain bikers. An opinion poll from 2011 found that $71 \%$ of Czechs do not agree with building of a new ski-lift and downhill skiing run in Šumava NP. ${ }^{27}$ The Bills' proposals will result in significant loss of non-use value from Šumava NP, and reputational damage to Šumava region and the Czech Republic's record of natural heritage protection.

\section{Local Economic Activity and Employment}

Under the drafted Bills, job opportunities could increase in the NP through:

- construction work related to tourism and relaxed protections in the NP;

- increased forest management;

- any increases in tourism as a result of developments.

Increased construction work as a result of reduced protection will bring a temporary increase in jobs. How-

\footnotetext{
26 http://ec.europa.eu/environment/nature/natura2000/wilderness /index_en.htm

27 Factum Invenio (2011) http://www.hnutiduha.cz/aktualne/71-lidi-je -proti-novym-lanovkam-sjezdovkam-v-narodnim-parku-na-sumave
}

ever, these jobs will be short term, and construction work is often taken by mobile labour from outside local areas.

With a reduction in non-intervention zones, increased active management of the NP will potentially result in more job opportunities in direct management. However, it is unclear if an increase in management will increase unemployment in the local population, because at present these jobs are not all taken by the local workforce. Furthermore, the damage to the park's condition and reputation could reduce local job opportunities, currently and in future, related to nature-based tourism - as outlined above, it is likely that developments arising from the Bills will undermine the international market image for Šumava among nature-based and general recreation visitors.

However, even if there is an increase in visitors - e.g. winter skiers - associated with the development activity and it is also expected that jobs in tourism may increase, the extent to which the economic benefits from any increase in tourism remains in the local area depends on the ownership and employment structure of the tourism industry. Increased tourism concentrated on a single activity and site (skiing), is more likely to require large scale facilities that are owned and controlled by people from outside the region. This increases the leakage of tourism revenues from the local area. Training is likely be required in the local unemployed workforce to access any opportunities that arise from increased development to overcome a skills shortage.

Comparing the key activities of forestry and nature-based tourism, the import of forestry labour means that it is likely to have lower value-added within the local economy compared to tourism activity. This will result in a lower proportion of income remaining within the local economy, and as a result lower tax revenues to local Government.

\section{Financial Viability}

Significant costs are associated with the adoption of the draft Bills. Constructing new trails, development of new tourist infrastructure and a ski lift require large capital investment. Public (national and European) and private financing is required. It is uncertain whether the investments required will be profitable enough to attract significant private financing. Using public funds to support the investments is questionable given that they will reduce the ecological value of the National Park. European Commission financing should not be provided for any project that damages a Natura 2000 site.

The new developments could potentially bring new revenues to the National Park, but as discussed under Tourism above, there is a risk of the ski lift proving non-viable, meaning this financial return is not achieved. The reduced ecological value of the site would make it harder to access European funding (e.g. LIFE funds to develop the nature conservation interest, or Structural Funds to develop nature-based tourism facilities). 
The Bavarian Forest (Bayerischer Wald) NP has 53\% wilderness area and supports a healthy tourism industry: based around the iconic value of the wilderness "brand", the natural landscape, feeling of remoteness that goes with it - all key marketing elements.

The Bavarian Forest NP attracts around 750,000 visitors per year, which bring expenditure of $€ 13.5$ million per year. It directly employs 200 people and indirectly 939 from tourism, a total of 1,139 jobs. Every euro spent on the national park by the Bavarian Government is doubled by tourism spend in the park (Nationalparkverwaltung Bayerischer Wald 2010).

It is demonstrated that in the Bavarian Forest that the opportunity $\operatorname{costs}^{28}$ of the National Park are far exceeded by the benefits from nature-based tourism. This means that tourism compensates the region for lost income in the forestry and wood-processing sectors as a result of protections offered by the NP.

It is worth emphasizing that the logging income that does exist almost completely flows out of the region, because of remote ownership of the operations, while a higher proportion of tourism income stays in the region. These circumstances closely follow those experienced in Šumava NP, but the Bavarian Forest has made a choice to protect the nature and is seeing associated tourism benefits.

An important study in 2010 demonstrates the potential opportunities in NPs. Mayer et al. (2010) analyses the economic impact of tourism in six German national parks. It shows that the NP is a driver of development and substantial opportunities exist based on the protection and expansion of the non-intervention wilderness areas of high value nature in Šumava NP.

The key findings analysis of the German NPs were:

- Between $32 \%$ and $35 \%$ of income is retained in national parks; $16 \%$ is converted into indirect regional income.

- Encouraging visitors to stay overnight will increase the economic impact as will increasing the quality of service which will increase the prices of services.

- Bayerischer Wald NP is a strong tourist attraction, but it could be doing more to co-ordinate marketing and tourism businesses. For example promoting regional products will keep economic impact in the region.

Box 2 Evidence from German NPs.

\section{Pro-Wilderness Development}

\section{Tourism}

As shown by Těšitel et al. (2003), tourists visiting Šumava appreciate the pristine nature of the NP. In 2011, $45 \%$ of visitors surveyed support the idea of having $30-40 \%$ of the NP as non-intervention zones, $36 \%$ support more than $40 \%$. Also $68 \%$ of respondents disliked clear cuts and $52 \%$ of visitors surveyed do not mind the sight of dead trees. ${ }^{29}$ Leveraging this aspect of the Šumava NP is important for any development. This echoes what is found in the Bavarian Forest, where bark beetle is accepted as a natural process. ${ }^{30}$ These findings suggests that large non-intervention areas would not repel tourists, but that visitors support an increase in the non-intervention Zone and therefore show affinity with "wild" natural areas.

The best access points to the Šumava NP's wilderness are currently regarded as being "full" in that further increases in visitors would damage the "wilderness" experience which draws visitors. Therefore, there is perceived to be demand for a larger number of carefully managed access points to a larger wilderness area.

In line with this, and as recognised by the Šumava Regional Development Agency in 2007, an opportunity lies in marketing Šumava as a region of "unique nature and scenery values" and a risk to the landscape lies in "... ill conceived investment activities" (Picek et al. 2007). In-

28 Opportunity cost refers to the lost benefits from pursuing a certain course of action. For example an opportunity cost of national park designation is the net value of all the timber protected.

29 Source: Šumava NP Visitors Questionnaire http://www.hnutiduha.cz /sites/default/files/publikace/2013/vystupy_anketa_sumava_2011.pdf

30 For example http://www.dw.de/the-bavarian-forest-a-story-of -regeneration/a-1079118 creasing the size of the core Zone to $52.2 \%$ would provide Sumava with recognition as a protected area of international importance. The Šumava NP would be adopting a strategy which is supporting the economic benefits associated with wilderness. Wilderness areas are rare in central Europe, and the presence of a significant wilderness area in the region will provide a draw to visitors.

The current extent and size of the potential activity at the Šumava NP in nature tourism are demonstrated by recent analysis of the tourism benefits of Natura 2000 sites. It found that tourism expenditure in Natura 2000 sites was $€ 50-€ 85$ billion a year (European Union, 2013). This expenditure is estimated to support from 800,000 to 2 million FTE jobs. This activity is related to ecotourism, which has a large and growing global market (see Annex 4).

A number of actions could be undertaken to develop Šumava NP's share of this substantial nature tourism market. Firstly, securing its conservation status would provide greater certainty for visitors and those investing in services for this market, as would support by government. Secondly, specialist nature-tourism analysis of the visitor offer could be undertaken to identify the most effective enhancements to local infrastructure and services. Thirdly, the visitor offer could then be marketed, including through a formal linkage between Šumava and Bavarian Forest NP (see Box 2). Tourism information leaflets developed in the past by the NP on wilderness and mountain spruce regeneration are no longer available in NP information centers or local accommodation services. This indicates the potential to increase the marketing efforts based on the nature-based tourism offer in the Park.

Increasing nature-based tourism activity could be done, at least initially, by making greater use of existing 
tourism capacity. As well as underemployment of the local workforce, there is evidence of underutilised capacity in guest houses, hotels and other accommodation (G. Whiteley, pers. comm.). More effective marketing to visitors to promote Šumava NP's natural wild heritage could firstly aim to increase use of existing accommodation, and secondly to expand facilities, including accommodation in existing villages, and provide visitor facilities around new points of carefully managed access to a larger wilderness area.

One factor such a development package could target would be to expand the tourism season using existing tourism activities in local communities. For example by providing further cross country skiing opportunities with the nature-based or landscape-based selling point of the NP. A benefit of this cross-country skiing tourism is that it supports economic activity in the winter season.

The following tourism development opportunities have been identified for Šumava and lead on from the Mayer et al. (2010) study. Not all of these opportunities are inexorably linked to an increased non-intervention zone, but it is difficult to imagine these ideas succeeding if the landscapes and nature of Šumava is not adequately protected.

\section{Nature-based Tourism}

With increases in protection for natural habitats, plus better low-level local infrastructure, services and marketing, those tourist activities which rely on nature can be increased. This applies to some extent to all activities in the NP, but is particularly relevant to activities which rely on interaction with nature (including bird watching, wildlife watching). These activities are currently underdeveloped in Šumava NP - increased protection for habitats will support the development and marketing of these activities.

These activities can contribute a significant amount to tourism revenue: in the United States bird watchers contribute $\$ 85$ billion annually in economic output, creating 863,405 jobs (Pullis La Rouche 2006). The potential scale of the market of people interested in birds and nature conservation from which Šumava NP would be looking to attract nature-tourism visitors is indicated by NGO memberships. The BirdLife European and Central Asian Partnership consists of 45 conservation organisations with approximately 1.9 million members, the majority of which are in Europe, and BUND (Friends of the Earth Germany) have 0.5 million members. These people provide a potential market of tourists motivated by nature-watching, which can be grown by increased quantities of wildlife in the non-intervention Zone, and in areas outside the non-intervention Zone, where species should also increase due to spill over effects.

Key aspects of Šumava's nature-based tourism offer would be populations of iconic species (e.g. birds such as capercaillie, black grouse, birds of prey) as well as its overall richness of forest and wetland ecosystems to- gether with their wildlife (e.g. orchids, many insects, including beetles and butterflies) and particularly the wild landscape.

An increase in nature-based tourism can be attracted to the Park by specific development of facilities such as: - improvement of nature trails, including replacing asphalt roads with access walking routes more in keeping with access to a wilderness area;

- observation towers and visitor centre(s) that allow visitors to learn about and see, but not disturb the species/environment they wish to encounter;

- development of enclosures where people can view wildlife such as red deer during the winter season (e.g. at Velký Bor, Beranky and Jelení Vrchy) and potentially wolves (near Srní);

- increased provision of guided walks into the Park; these are currently offered (e.g. at Křemelná, Vltavský luh, Trojmezná, Smrčina, Modravsko, Polom, Ždánidla, Kamenná) by the Park administration, but usually sell out within a few days of being announced; this suggests demand is not being met and greater numbers of trips could be organised at other locations (e.g. around peat bogs around Kvilda and Weitfallernske, in "succession forests" at Stodůlky, Skelná, Vysoké Lávky or Cetlova Hůrka) attracting more visitors to the area.

These can be supported through development of widespread low-level provision of facilities (e.g. accommodation, catering) in local communities close to the best areas for activities. It can generate income and employment through tour guiding, accommodation, restaurant, transport provision, craft marketing, and other retail. Such developments require some investments, but compared to the skiing developments under the proposed bills, these are significantly less expensive. Also, being spread across a number of locations, they can be developed over time and in a way that spreads risks away from a single location.

An expanded non-intervention area would increase the potential for nature-based tourism as described above. It would also enable alteration of current access points that disturb rare species (e.g. capercaillie breeding areas) through provision of alternative wilderness access points.

A beneficial aspect of nature-based tourism is that it often takes place outside the peak tourism season (Rayment and Dickie 2001). For example, in 2000, the RSPB established Capercaillie viewing ("Caper-watch") at its Loch Garten reserve in the highlands of Scotland. It has since attracted over 10,000 visitors, who bring increased tourism trade, estimated at around $£ 90,000$ (approximately $€ 100,000$, in 2006 prices) each year, to the area outside the peak holiday season (Dickie et al. 2006).

Low-level provision of nature tourism based on local communities can generate income and employment through tour guiding, accommodation, restaurants, 
transport provision, craft marketing, and low level retail. Under plans for expanding the non-intervention zone a more sustainable economic development model can be established - combining: 1) low level, local development within the park based on nature tourism, etc; and 2) development and improved productivity of activities in adjacent areas outside the NP.

\section{Strong Šumava Brand}

Strengthening the brand or identity of Šumava, particularly in connection to wildness and the wilderness experience, will help attract national and international tourists to the region. Acting to protect a larger area of Sumava NP will enhance the region's nature credentials and therefore increase the attraction for tourists. From this the park can apply for international awards to be applied to the park, such as Pan Parks or IUCN category II, which currently the park is looking like it will lose.

At present there is limited promotion of the National Park by accommodation and tourist providers in the region and there are very limited tourism-orientated products. Despite the existence of a Šumava Region product range, ${ }^{31}$ it does not appear to tie into the existence of the national park. The product certification that exists at present is not unique to Šumava, and does not utilise the natural assets of Sumava. There is an opportunity to develop the marketing of local produce using a Šumava brand that links to the unique nature-based image for Sumava that would develop under this scenario. This in turn could enhance the visitor experience of Šumava NP.

A good example to follow could be the use of the Yorkshire Dales NP logo. ${ }^{32}$ Local business and producers sign a licence agreement and pay $£ 50$ (€58) to use the logo. The reasons for using the logo are given as follows: "The Yorkshire Dales NP logo - the well-known Swaledale ram's head ${ }^{33}$ - provides a strong identity for this beautiful area. The logo promotes the location, provides a sense of place, and is a strong brand which is recognised nationally."

A way to strengthen the brand of the Šumava NP is by restarting the "Wild Heart of Europe" initiative. The Bavarian Forest, on the German side, is often cited as a model for management based on non-intervention, that could be applied in Šmava NP. They have adopted a successful tourism industry based on a wilderness-like experience (see Box 2). In the past there have been discussions on enhancing links between the two parks, which would allow their combined marketing as the "Wild Heart of Europe".

A previous attempt to market the two national parks in this way was restricted by differences in management approaches in the two countries. A pro-wilderness man-

$31 \mathrm{http}: / / w w w . r e g i o n a l-p r o d u c t s . e u / e n / b r a n d s / d e t a i l / 375 /$ sumava-originalni -produkt

32 http://www.yorkshiredales.org.uk/livinghere/whatwecandotohelpyou $/ \log 0$

33 This is the head of a type of sheep associated with farming in the area. agement plan in Šumava NP would have synergy with the management approach in the Bavarian Forest. This would enable coordination of management and development of low-impact facilities for visitors to Šmava with those in the Bavarian Forest. For example, networks of trails could be coordinated across the border. This could resume use of the Wild Heart of Europe brand, presenting a significant marketing opportunity for tourism and sharing of visitor management and enterprise experience.

\section{Higher Value Services}

With the development of a unique brand, location and experience, correspondingly higher value tourism services can be supported by the park. High value services result in each tourist spending more money on services during their visit. This must be based on offering a wider range of services with higher-valued-added to tourists. Such services need to be of higher quality to ensure increased revenues. Support would be required at a local level to enable this, for example through international standard accreditation for accommodation \& services; training for staff; communications support to overcome language barriers for international marketing; and support for planning and funding local businesses.

The following ideas are examples of higher value tourism opportunities:

- high quality restaurants offering local produce;

- increased options for guided tours;

- high quality camping and caravan sites;

- high quality package tours - with many of the services provided locally to keep value added in the region, although experience of existing wilderness operators is valuable; ${ }^{34}$

- kit transport services (e.g. for cyclists/walkers) to take their overnight bags to the hotel/ campsite that they cycle or walk to through the wilderness areas;

- new, better and more extensive visitor centres;

- opportunity for local crafts, retail sales;

- use of Wild Heart/wilderness brand for locally produced goods and services - including produce from areas adjacent to non-intervention Zone;

- promotional events linked to the characteristics of the NP (e.g. a "wilderness festival") held in the communities in and around the NP, with a concentration of activities (e.g. for families) to attract new visitors to the area.

Neil Birnie, a nature-tourism expert, ${ }^{35}$ commented on the nature-tourism opportunity that: "Šumava Nation-

34 Examples of tour operators http://wilderness-travel.org/

$35 \mathrm{Mr}$ Birnie is Founder of Wilderness Scotland/Wilderness Journeys, which was recently recognized as Europe's No 1 Adventure Travel Company by National Geographic and winner of the Best Green Tour Operator category at the World Travel Awards. He is Chief Executive of Conservation Capital which has structured transactions in excess of US\$ 200 million in more than 20 countries across Africa and Europe. 
al Park is ideally positioned to capitalise upon positive trends within the wider global tourism industry, with travellers increasingly seeking experiences based upon wilderness and wild nature. The Park's geographical proximity to major centres of European population gives it a significant competitive advantage over other areas of wilderness character.

The key elements required to capitalise upon this opportunity are:

- Creative product development: building upon existing offerings (outdoor activities and local guesthouse style accommodation) and focusing upon products of higher value potential such as upmarket wilderness "ecolodge" accommodations, imaginative family-focused experiences and wildlife tourism.

- Training and skills development in the core service skills of guiding and tourism facility management.

- Investment in international marketing efforts to promote Šumava as a destination, with such promotional efforts carefully coordinated so as to complement individual business marketing strategies."

These nature-based tourism developments can be a source for project based (EU) investment to the region. For example, EU Structural Funds 2014-2020 will continue to provide support to tourism related SME development and capacity building etc., including cross-border developments (M. Kettunen, IEEP, pers. comm., Nov. 2013). A feasibility study is recommended to identify specific development opportunities and what support they would require.

\section{Research and Education}

Although not what is usually thought of as tourism, the creation of the large wilderness area would attract scientific researchers, whose requirements can be similar to nature-tourists in terms of accommodation and other services. These scientists can bring with them similar revenues to tourists. A research and training centre was proposed in Kvilda in the centre of the NP, looking to attract scientists and also offering a unique opportunity for interpretation of field science to the public (e.g. using recently developed technologies that allow online tracking through radio tags of individuals of charismatic species). With the change in park leadership the research centre project was shelved, but could be revived.

A large wilderness area will also be attractive to schools and students, national and international, including through overnight stays on educational trips, and in environmentally-focused holiday camps.

\section{Hunting}

Hunting is currently of limited importance to the National Park. Due to the loss of large natural predators in the NP (bears and wolves), traditional prey species such as deer have no pressure from predation. This large population of deer causes problems for the environment of the national park. For this reason culling is considered good environmental management.

At present the local population employed in forest management are obliged to shoot 10 deer a year; 686 red deer were shot in 2011 (Křenová, pers. comm., July 2013). This is a potential income stream that is not being exploited, as some of these deer could be shot by hunting-tourists. Hunting is offered in the Czech Republic with up to $€ 600$ charged to shoot a roe deer, ${ }^{36}$ excluding any additional services.

Although not directly tied to the size of the non-intervention area, marketing which leverages hunting in the "Wild Heart of Europe" will be attractive. Hunting may not be suitable in the majority of the NP, as it would not be in line with "non-intervention" management. However, given that some deer culling is already taking place, a carefully managed system of permitted hunting should be possible. Its management would need to balance the benefits of reduced deer populations to habitat management, the local revenue from hunting, and the detrimental impact on species viewing by non-hunting visitors (as hunting makes all large species more wary of humans).

\section{Regulating Ecosystem Services}

It is difficult to determine the exact impact on ecosystem services of a large non-intervention area without understanding the ecosystem services that flow from Sumava NP in considerable detail. Under the pro-wilderness scenario, the protection of ecosystems, and the reduced fragmentation of habitats and intervention management, are likely to increase the value of regulating services, compared to the current scenario. For example, less use of intervention forest management is likely to increase carbon being stored into the soil, and increase regulation of water runoff.

The significance of these changes cannot be quantified without detailed analysis and/or modelling of the Sumava landscape. However, there is an opportunity under this pro-wilderness scenario to restore and manage wetlands to enhance their regulating services values.

\section{Non-use and Existence Values, and Reputation}

As discussed in the section Non-use and Existence Values, and Reputation, the public values conservation of wildlife, particularly in the areas of highest quality habitats and species (such as Šmava NP). The creation of a larger non-intervention area will increase the level of these values for Šmava NP. It could also improve the reputation of Šmava as a sustainably managed NP. This links to the tourism market opportunities described above.

$75 \%$ of the Czech population agree that it is important to halt the loss of biodiversity because we have a moral obligation to look after nature. ${ }^{37}$

\footnotetext{
36 http://www.stanislavstur.cz/download/Hunting\%20in\%20the\%20 Czech\%20Republic\%20with\%20Stanislavstur.pdf

37 http://ec.europa.eu/public_opinion/flash/fl_379_fact_cz_en.pdf
} 


\section{Local Economic Activity and Employment}

Concern exists that any substantial increase in size of the non-intervention area would result in job losses of local people in the NP area. This is considered unlikely for a number of reasons. Firstly, unemployment in Šumava $\mathrm{NP}$ is closely following national trends (although generally having lower rates of unemployment) irrespective of the management of the park over the last two decades (see Fig. 5). This suggests that the main drivers of local employment are the performance of the national economy and the skills of the local workforce - not the mode of management employed.

Secondly, the prospects for losing employment in forestry activities are low. Forest management is not likely to decrease in the event of an increase in non-intervention area. The fear that forest management work would be reduced, if the non-intervention area was increased, rests on the assumption that the current area is fully utilising all opportunities for employment. However, this is not the case. Even though the non-intervention area will increase under this scenario, there will still remain substantial areas (estimated to be at least $160 \mathrm{~km}^{2}$ ) that will continue to support existing levels of activity by lumberjacks/foresters. The need for cyclical bark beetle management activity will also remain in some areas.

In addition, the work of foresters does not only include chopping trees down, but also replanting. An area of $951.52 \mathrm{ha}^{38}$ remains to be forested, this work is a legal requirement and is required whatever the extent of non-intervention zones, so should provide a stable source of employment. Anecdotal evidence (Guy Whiteley, pers. comm. during the visit in July 2013) from the local population suggests that the present management of the forest is undertaken by companies that employ a non-local workforce. Therefore, the impact of any reduction in forest management activity (if it did occur) will not all fall on the local population. Therefore, an increase in the non-intervention zone will not necessarily have any impact on forestry employment, nor employment within local communities.

Thirdly, the scenario of natural ecosystem (wilderness) expansion brings a better opportunity for creating new local employment in and around Šumava NP. This opportunity is based on long term expansion of nature-based tourism based on opportunities and branding associated with a large transboundary wilderness zone (described in section Tourism).

Finally, there is some perception that there are sufficient jobs in the national park for the majority of individuals who have the requisite skillset. What the area around the national park might be experiencing is structural unemployment, whereby the skills and education of the workforce do not match the demand for jobs. ${ }^{39}$ Anec-

38 http://www.czso.cz/vykazy/vykazy.nsf/i/les_8_01_2012

39 http://www.brookings.edu/research/papers/2011/09/09-skills -unemployment-rothwell-berube

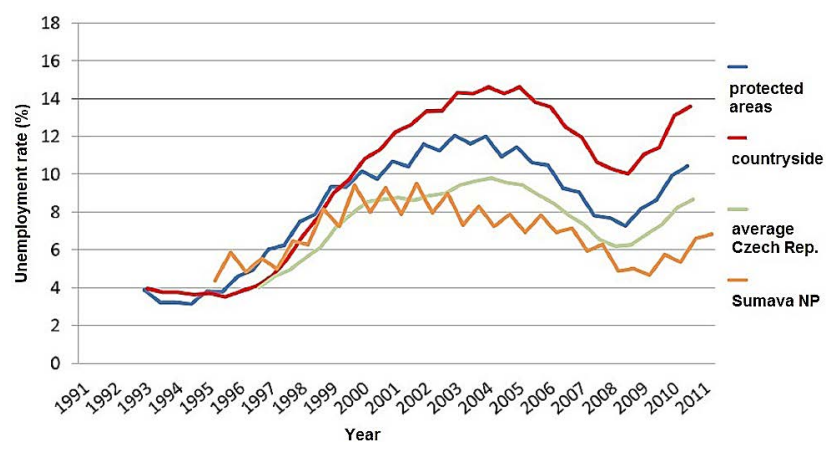

Fig. 5 Employment trends in Šumava and related areas.

dotal evidence suggests this is the case in Šmava - suggesting a need to provide appropriate training to match the local workforce the job opportunities associated with expanded tourism activity.

In Annex 3 we present a number of studies that show the revenue generation and employment opportunities generated by NPs and wilderness.

Overall pro-wilderness development is likely to have a positive impact on local employment. Forestry employment is likely to be maintained. Expansion and enhancement of the tourism offer can increase the employment opportunities it offers. Under this scenario it can also support activities which have a greater value added, and therefore result in more income and indirect activity supported, within the local economy.

\section{Financial Viability}

Leaving a substantial part of the national park to wilderness can be seen as a more cost-effective option. The land that has been designated as a non-intervention area would be left without ongoing habitat management (although visitor management could be required). It is unlikely that any intervention would be required in designated core areas, but there would still be other employment opportunities in conservation management: anti-poaching, information provision, guidance, research. Rangers would ensure borders are respected and tourist activities are not damaging habitats.

This scenario would provide local development opportunities that do not damage the ecological value of the Park. This would make it easier for the areas to access European funding (e.g. LIFE funds to develop the nature conservation interest, or Structural Funds to develop nature-based tourism facilities).

Under this scenario opportunities to generate revenue to enable the NP to be managed effectively could also increase through:

\section{Entry Fees}

Entry fees could be charged for certain areas of the park, or access to specific new facilities or opportunities (e.g. canoeing routes). This would be a direct way to generate income to finance park activities, thus supporting jobs. Entry fees are not politically or practically possible 
across the whole of the national park. They may be possible on small areas of the park where a unique experience is provided, e.g. at the Poledník viewing tower; for canoeing on the upper Vltava river; entrance to red deer enclosures.

\section{Payments for Ecosystem Services (PES)}

New forms of financing and funding for nature are being considered across Europe. ${ }^{40}$ These new funding streams could support jobs and management activities in the National Park.

One of these is PES, which refers to the beneficiaries of ecosystem services paying to ensure that these services continue or are enhanced. To assess the full potential for PES in the Šumava NP a full assessment of the ecosystem services provided and the beneficiaries would be required (building on the information in Annex 1). PES opportunities could also exist for a range of regulating ecosystem services including water quality, carbon sequestration and flood mitigation.

Voluntary donations to the running of the NP are also a form of PES. The key question is how to collect these donations. To maximise revenue it is best to collect donations at a bottleneck that most visitors flow through and it is beneficial to ask for a donation when customers are already spending money. ${ }^{41}$ This could occur at either a centralised hotel booking site, or at check in/out at hotels who have signed up to be Šumava NP partners.

Excellent information materials have been produced by the National Park. These can be provided in hard copy or electronically to tourists who pay a voluntary donation to the park. A link to the donation page can be provided at hotels and tourists information points. This is of low or zero marginal cost to the national park authorities (no printing charges) and the documents already exist. It could form part of plans for improved marketing to underpin gains from nature-based tourism (see section Tourism). It could form part of plans for improved marketing to underpin gains from alternative wilderness based tourism (see section Tourism).

These are initial ideas and require further development. They illustrate that substantially increased revenue streams could be possible from the park.

\section{Acknowledgements}

This research was supported by the grants No. 14-36098G of the GA CR and No. CZ.1.05/1.1.00/02.0073 of the MSMT.

\footnotetext{
40 See http://www.prosperousparks.com/ or

http://ec.europa.eu/environment/enveco/biodiversity/pdf/BD _Finance_summary-300312.pdf

$41 \mathrm{http}: / /$ www.research-live.com/comment/tugging-on-the-behavioural -heartstrings/4007544.article
}

\section{REFERENCES}

Abensperg-Traun M, Smith GT (1999) How small is too small for small animals? Four terrestrial arthropod species in different-sized remnant woodlands in agricultural Western Australia. Biodivers Conserv 8: 709-726.

Berger J (1990) Persistence of different-sized populations: An empirical assessment of rapid extinctions in bighorn sheep. Conserv Biol 4: 91-98.

Berger J (1999) Intervention and persistence in small populations of bighorn sheep. Conserv Biol 13: 432-435.

Bláha J (2012) Threats to wilderness in Šumava - how European Citizens can help wilderness, presentation. Available from: http://www.slideshare.net/panparks/jaromir-blaha-threats-to -wilderness-in-sumava-how-european-citizens-can-help -wilderness [accessed 23. 11. 2013].

Bláha J, Romportl D, Křenová Z (2013) Can Natura 2000 mapping be used to Zone the Šumava National Park. Eur J Environ Sci 3: $57-64$.

Bulman CR and 6 others (2007) Minimum viable metapopulation size, extinction debt, and the conservation of a declining species. Ecol Appl 17: 1460-1473.

Cumulus Consultants Ltd and ICF GHK (2013) Valuing England's National Parks: Final Report for Natural ParksEngland. Available from:http://www.nationalparksengland.org.uk/_data/assets/pdf _file/0006/338361/Valuing-Englands-National-Parks -Final-Report-10-5-13.pdf [accessed on: 23. 11. 2013].

Defra (2011) National Park Authorities: Assessment of Benefits - working paper. Available from: https://www.gov.uk /government/uploads/system/uploads/attachment_data/file /69310/pb13533-national-park-authorities.pdf [accessed on: 23. 11. 2013].

Dickie I, Hughes J, Esteban A (2006) Watched Like Never Before. RSPB. Sandy. Available from: https://www.rspb.org.uk /Images/watchedlikeneverbefore_tcm9-133081.pdf[accessed on: 23. 11. 2013].

European Commission (2013) Factsheet: The Economic Benefits of Natura 2000, European Union.

Font X, Cochrane J, Tapper R (2004) Tourism for Protected Area Financing: Understanding tourism revenues for effective management plans' WWF, World Wide Fund for Nature. Available from: http://www.panparks.org/sites/default/files/docs /publications-resources/pay_per_nature_view_-_understanding _tourism_revenues_for_effective_management_plans.pdf [accessed on: 23. 11. 2013].

Franklin IR (1980) Evolutionary change in small populations. In: Soulé ME, Wilcox BA (eds.) Conservation Biology: An Evolutionary-Ecological Perspective, pp. 135-149. Sinauer Associates, Sunderland, MA.

Frelichová J, Vačkář D et al. (2013) Integrated assessment of ecosystem services in the Czech Republic. Global Change Research Centre AS CR, Brno.

Getzner M (2009) Economic and cultural values related to Protected Areas: Part A: A valuation of Ecosystems Services in Tatra (PL) and Slovenský ráj (SK) national parks. WWF, World Wide Fund for Nature. Available from: http://www.panparks .org/sites/default/files/docs/publications-resources/economic _and_cultural_values_related_to_protected_areas.pdf [accessed on: 23. 11. 2013]

Gilpin ME, Soulé ME (1986) Minimum viable populations: Processes of species extinction. In: Soulé ME (ed.) Conservation Biology: The Science of Scarcity and Diversity, pp. 19-34. Sinauer Associates, Sunderland, MA. 
Gorner T, Najmanová K, Čihař M (2012) Changes in Local People's Perceptions of the Šumava National Park in the Czech Republic over a Ten Year Period (1998-2008). Sustainability 2012: 1354-1370; doi: 10.3390/su4061354.

Gorner T, Čihař M (2013) Local Attitudes on Protected Areas: Evidence from Šumava National Park and Šumava Protected Landscape Area. Environ Pollut 2: 1-13.

Grodzki W, Jakuš R, Lajzová E, Sitková Z, Maczka T, Škvarenina J (2006) Effects of intensive versus no management strategies during an outbreak of the bark beetle Ips typographus (L.) (Col.: Curculionidae, Scolytinae) in the Tatra Mts. in Poland and Slovakia. Ann Forest Sci 63: 55-61.

Groom MJ, Meffe GK, Carroll CR (eds.) (2006) Principles of Conservation Biology, 3rd ed. Sinauer Associates, Sunderland, MA.

Harris G, Pimm SL (2008) Range size and extinction risk in forest birds. Conserv Biol 22: 163-171.

Headwaters Economics (2013) Summary Report: The Economic Costs and Benefits of a New National Park and Recreation Area for Penobscot and Piscataquis Counties, Maine. Headwaters Economics.

Holmes FP, Hecox WE (2004) Does wilderness impoverish rural regions? Int J Wilder 10: 34-39. Available from: http://www .wilderness.net/library/documents/IJWDec04_Holmes.pdf [accessed on: 23. 11. 2013].

IEEP, Brink P, Badura T, Bassi S, Gantioler S, Kettunen M (2011) Estimating the Overall Economic Value of the Benefits provided by the Natura 2000 Network. Institute for European Environmental Policy (IEEP).

Kindlmann P, Matějka K, Doležal P (2012) Lesy Šumavy, lýkožrout a ochrana prírody. [Forests of Šumava, bark beetle and nature protection. In Czech] Karolinum, Prague.

Křenová Z, Hruška J (2012) Proper zonation - An essential tool for the future Conservation of the Šumava National Park. Eur J Environ Sci 2: 62-72.

Křenová Z, Kiener H (2012) Europe's Wild Heart - still beating? Experiences from a new transboundary wilderness area in the middle of the old continent. Eur J Environ Sci 2: 115-124.

Lake District National Park (2011) Tourism, the economy and the local community. Available at: http://www.lakedistrict.gov.uk /learning/lakedistrictfacts/factstourism/factstourismeconomy [accessed on: 23. 11. 2013].

Lawton JH, Brotherton PNM, Brown VK, Elphick C, Fitter AH, Forshaw J, Haddow RW, Hilborne S, Leafe RN, Mace GM, Southgate MP, Sutherland WJ, Tew TE, Varley J, Wynne GR (2010) Making Space for Nature: a review of England's wildlife sites and ecological network. Report to Defra.

MacArthur RH, Wilson EO (1967) The Theory of Island Biogeography. Princeton University Press, Princeton, NJ.

Mayer M, Müller M, Woltering M, Arnegger J, Job H (2010) The economic impact of tourism in six German national parks. Landscape Urban Plan 97: 73-82.
Müller JB, Bußler H, Goßner H (2008) The European spruce bark beetle Ips typographus in a national park: from pest to keystone species. Biodivers Conserv 17: 2979-3001.

Nationalparkverwaltung Bayerischer Wald (2010) The regional economic impact of Bavarian Forest National Park.

Pardini R, de Souza SM, Braga-Neto R, Metzger JP (2005) The role of forest structure, fragment size and corridors in maintaining small mammal abundance and diversity in an Atlantic forest landscape. Biol Conserv 12: 253-266.

Picek M, Růžička T, Silovský V, Těšitel J, Vlášková K (2007) Tourism in the Šumava mountains: Concept of sustainable tourism development. Action Programme. Issued by Regionální rozvojová agentura Šumava, o.p.s.

Policy Committee of the Society for Conservation Biology, Europe Section (2012) Report on the Trip to Šumava NP, Czech Republic.

Potočnik J (2012) Letter to Mr. Tomáš Chalupa, Minister of the Environment of the Czech Republic.

Pullis La Rouche G (2006) Birding in the United States: a demographic and economic analysis. In: Boere GC, Galbraith CA, Stroud DA (eds.) Waterbirds around the world. The Stationery Office, Edinburgh, UK, pp. 841-846.

Rayment M, Dickie I (2001) Conservation Works. RSPB. Sandy. http://www.rspb.org.uk/Images/conservationworks_tcm 9 -132933.pdf [accessed on: 23. 11. 2013].

SCNP, APRS (2011) Benefits of National Parks: Joint report by the Scottish Campaign for National Parks and the Association for the Protection of Rural Scotland. APRS Website. Available from: http://btckstorage.blob.core.windows.net /site1061/Projects/Scottish\%20National\%20Parks/11.09 $\% 20$ Benefits\%20of\%20National\%20Parks.pdf [accessed on: 23. 11. 2013].

Shaffer ML (1981) Minimum population sizes for species conservation. BioScience 31: 131-134.

TEEB - The Economics of Ecosystems and Biodiversity for National and International Policy Makers (2009) Summary: Responding to the Value of Nature. Available from: http://data.iucn.org /dbtw-wpd/edocs/2009-116.pdf [accessed on: 23. 11. 2013].

Těšitel J, Kušová D, Bartoš M (2003) Role of tourism in development of rural marginal areas (region of Šumava Mts. in Czech Republic). European Rural Development Network Studies 1: 81-91.

Traill LW, Bradshaw CJA, Brook BW (2007) Minimum viable population size: A meta analysis of 30 years of published estimates. Biol Conserv 139: 159-166.

Wilderness.net website, undated. Economic benefit of wilderness. Available online: http://www.wilderness.net/NWPS/values Economical [accessed on: 23. 11. 2013].

Willi Y, Van Buskirk J, Hoffmann AA (2006) Limits to the adaptive potential of small populations. Ann Rev Ecol Evol Syst 37: 433-458. 


\section{Annex 1 - Šumava Ecosystem Services Valuation}

The preliminary results from a study which estimates the ecosystem values of Šumava Region has been provided to us as part of this report. It provides an "order of magnitude" estimate of the values coming from the park. The study has undertaken a value transfer exercise, which takes primary values from other studies on similar habitat types and applies them to Šumava. It finds that $€ 1.1$ billion a year worth of ecosystem services flow from the park every year.

\section{Methodology [provided by study author David Vačkář]}

Valuation of ecosystems of Šumava has been based on habitat accounting approach which takes into account specific natural habitat units occurring in the case study area. Benefit transfer was the key method applied to obtain values. A use of this method enabled us to derive values of the ecosystem examined based on data which have been previously carried out to value similar goods and services in similar context (Liu et al. 2010).

The initial step was literature review. To collect input data on biophysical and economical values we followed specific searching strategy within Web of Science (WoS) and Scopus. We have applied predefined chains of keywords, which included "Ecosystem service ", "valuation", "assessment" and ecosystem type. As a complementary data resource we extracted the Ecosystem Service Valuation Database (ESVD), which has been compiled by the Ecosystem Services Partnership (ESP) and the existing Czech studies and national reports.

We considered studies published between 2000 and 2012 only. Additionally, the studies were required to include information about habitat type, per hectare value, methodology and origin of data. To ensure comparability of transferred data with Czech environmental, social, economic and political conditions, we used studies related to European countries and geographical Zone in between $44^{\circ}-56^{\circ} \mathrm{N}$. Findings in accordance with given criteria were included in the database of biophysical and economic values. In total, we were able to build a database of more than 200 records based on 58 source studies.

A diversified set of values in terms of economic and biophysical metrics has been attained from a literature review. Therefore, the values were converted into common metrics and, in case of monetary values, were standardized to euro per hectares per year using 2012 as the base year.

Once the values were standardized, we estimated average values of individual ecosystem services as well as a total value per hectare of selected ecosystems. A total value per hectare of ecosystem was counted as a sum of the means of available services values. Afterwards, we generated values of Czech ecosystems by an attribution of total values to a land use type based on the following formula:

$$
\mathrm{E}_{\mathrm{V}}=\mathrm{A}_{\mathrm{y}} \times \mathrm{V}_{\mathrm{ES}}
$$

where $E_{V}$ is a value of assessed ecosystem, Ay is the area (in ha) of ecosystem/land use type and $\mathrm{V}_{\mathrm{ES}}$ represents an assumed total value of given ecosystem/land use type per hectare (EUR 2012).

To be able to spatially reference the values, we created a map with proper distinction of habitats. Such a map was created in cooperation with the Nature Conservation Agency of the Czech Republic. The map was compiled based on all the major sources of land cover/land use data in the Czech Republic. The resulting consolidated layer comprises 40 categories of ecosystems, classified at four hierarchical levels.

In the last step, we valued the ecosystems of Šumava and illustrated their value by the map. The overall value of the ecosystems, or ecosystem services, respectively, for the Šumava Mts. is 1,690 million EUR per year. The value of ecosystems in the Šumava NP is estimated at 1,140 million EUR. Therefore, the average value per hectare for the whole Šumava area (NP and Protected Landscape Area) is 10,078 EUR/ha/year. For the area of the $\mathrm{NP}$, the average value per hectare is $16,749 \mathrm{EUR} / \mathrm{ha} /$ year (in 2012 prices).

\section{Interpretation (EFTEC)}

The method used gives an initial indication of the potential significance of ecosystem services from Šumava NP. For example, with $2 \mathrm{~m}$ visitors/yr, cultural values could clearly be substantial. The method transfers values based on habitat types, but it has not been possible to adjust these for other variables (e.g. population, substitutes), so the results are uncertain. The results are an order of magnitude estimate of the potential size of the ES benefits.

We have shown that the Šumava National Park is not only of importance for either the tourism it generates or the timber it provides, but also for the services it provides local, national and international populations. Less than they would be under and alternative management scenario.
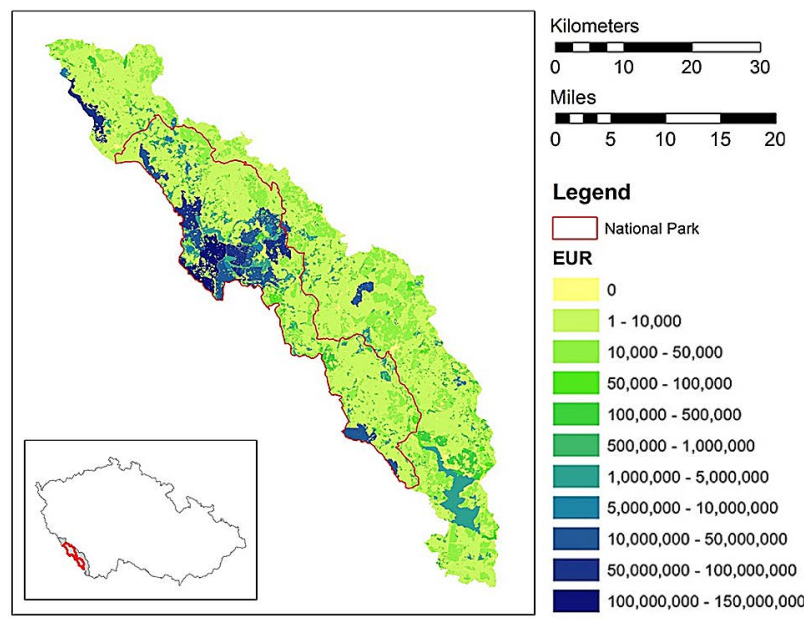

Fig. A.1 Estimate of value of ecosystem services from the Šumava National Park. 


\section{Ecosystem services valued}

Aesthetic value

Air quality regulation

Climate regulation

Disturbance regulation

Erosion regulation

Nutrient regulation

Pest control

Pollination

Provision biomass

Provision fish

Provision game

Provision non-timber

Provision timber

Provision water

Recreation

Water cycle regulation

Water quality regulation

\section{Ecosystem categories mapped in Šumava Mt.}

Alluvial forests

Alluvial meadows

Alpine grasslands

Anthropogenic water bodies

Anthropogenically influenced water courses

Arable land

Artificial rocks

Artificial urban green areas - parks, gardens, cemeteries

Artificial urban green areas - recreation and sport areas

Beech forests

Bog forests

Discontinuous urban fabric

Dry grasslands

Dry pine forests

Dump and construction units

Heaths

Industrial and commercial units
Intensive broad-leaved forests

Intensive coniferous forests

Intensive grasslands

Intensive mixed forests

Introduced Pinus mugo scrub

Introduced shrub vegetation

Macrophyte vegetation of water bodies

Mesic meadows

Natural Pinus mugo scrub

Natural rocks

Natural shrub vegetation

Natural water courses

Oak and oak-hornbeam forests

Orchards and gardens

Peat bogs and springs

Spruce forests

Swamps

Transport units

Wetlands and littoral vegetation

\section{REFERENCE}

Liu S, Costanza R, Troy A, Aagostino JD, Mates W (2010) Valuing New Jersey's Ecosystem Services and Natural Capital: A Spatially Explicit Benefit Transfer Approach. Environmental Management 45: 1271-1285.

\section{Acknowledgements}

Data and values has been provided within projects "Integrated Assessment of Ecosystem Services in the Czech Republic" and "Developing Long-term Social-ecological Research in the Czech Republic", funded by the Technology Agency of the Czech Republic and coordinated by the Global Change Research Centre, Academy of Sciences of the Czech Republic. 


\section{Annex 2 - Evidence for Existence Values}

Table A.1 Evidence for Existence Values.

\begin{tabular}{|c|c|c|}
\hline Paper & Question & Value \\
\hline $\begin{array}{l}\text { Amirnejad H, Khalilian S, Assareh MH, } \\
\text { Ahmadian M (2006) } \\
\text { Estimating the Existence Value of North } \\
\text { Forests of Iran by Using a Contingent } \\
\text { Valuation Method. Ecol Econ } 58: 665-675 \text {. }\end{array}$ & $\begin{array}{l}\text { Mean of willingness to pay (WTP) for existence } \\
\text { value of these forests }\end{array}$ & $\begin{array}{l}\text { US\$2.51 household/month } \\
\text { or } \\
\text { US } \$ 30.12 \text { household/year }\end{array}$ \\
\hline $\begin{array}{l}\text { Christie M, Hyde T, Cooper R, Fazey I, } \\
\text { Dennis P, Warren J, Colombo S, Hanley H } \\
\text { (2011) Economic valuation of the benefits } \\
\text { of ecosystem services delivered by the UK } \\
\text { Biodiversity Action Plan. Defra. }\end{array}$ & $\begin{array}{l}\text { The aim of this study was estimate the value } \\
\text { of changes in biodiversity } \\
\text { and associated ecosystem services resulting } \\
\text { directly from the delivery of the UK } \\
\text { Biodiversity } \\
\text { Action Plan (UK BAP). }\end{array}$ & $\begin{array}{l}\text { Two scenarios were developed, one } \\
\text { detailed the current benefits from UK BAP } \\
\text { implementation scenario. The second detailed } \\
\text { the benefits from increased spending on the } \\
\text { UK BAP. } \\
\text { The non-use benefits are as follows } \\
\text { Emillion/year } \\
\text { Sense of place - } 131.3-167.4 \\
\text { Charismatic species - } 253.7-175.1 \\
\text { Non-Charismatic species }-83.3-41.74\end{array}$ \\
\hline $\begin{array}{l}\text { Durand S, Point P (2000) Approche Théorique } \\
\text { Et Empirique De La Valeur D'Existence: } \\
\text { Application Aux Espèces Animales Protégées. } \\
\text { Chapitre } 3 \text { in: Méthode d'évaluation } \\
\text { contingente et décision publique, pp. 58-94. }\end{array}$ & $\begin{array}{l}\text { This study attempts at valuing existence value } \\
\text { of three protected species (bear, mink and } \\
\text { sturgeon) }\end{array}$ & $\begin{array}{l}\text { Existence value: } \\
\text { Sturgeon } 73.27 \text { per person } \\
\text { Bear } 160.85 \text { per person } \\
\text { Mink } 85.65 \text { per person } \\
\text { WTP in } 1999 \text { French Francs }\end{array}$ \\
\hline $\begin{array}{l}\text { Rollins K, Gunning-Trant C, Lyke A (1998) } \\
\text { Estimating Existence Values For Four Proposed } \\
\text { Park Sites In The Northwest Territories: } \\
\text { Bluenose Lake And Melville Hills, East Arm } \\
\text { Of Great Slave Lake, North Baffin And Bylott } \\
\text { Island And Wager Bay. Parks Canada }\end{array}$ & $\begin{array}{l}\text { The mean WTP for the creation of one, two } \\
\text { and four more national parks. }\end{array}$ & $\begin{array}{l}\text { Based on the data collected from the mail } \\
\text { survey, the mean WTP for the creation of one } \\
\text { more national park was assessed at } \$ 105.45 \text {, } \\
\text { at } \$ 161.85 \text { for two parks, at } \$ 191.57 \text { for four } \\
\text { parks, and } \$ 261.51 \text { for ten parks (Canadian } \\
\text { Dollars, CAD, 1995). } \\
\text { The mean WTP from the mixed-mode survey } \\
\text { was assessed at } \$ 250.69 \text { for the creation of } \\
\text { four parks and } \$ 282.87 \text { for the creation of ten } \\
\text { parks (CAD, 1996). }\end{array}$ \\
\hline
\end{tabular}




\section{Annex 3 - Benefits of NPs and Wilderness Areas}

\begin{tabular}{|c|c|c|c|}
\hline Reference & Comment & Revenue & Jobs \\
\hline $\begin{array}{l}\text { Defra (2011) NP } \\
\text { Authorities }\end{array}$ & $\begin{array}{l}\text { Looks at the added value of NPs, longer term } \\
\text { funding mechanisms and Defra/Government } \\
\text { priorities. }\end{array}$ & $\begin{array}{l}\text { Yorkshire and Humber: } \\
£ 1.8 \text { bn of sales. } \\
£ 576 \mathrm{mn} \text { Gross Value } \\
\text { Added (GVA). } \\
\text { The Broads: } \\
\text { Total annual value: } \\
£ 124 \mathrm{mn} \\
\text { Dartmoor NP (annual): } \\
\text { Over } £ 100 \mathrm{mn}\end{array}$ & $\begin{array}{l}\text { Yorkshire and Humber: } \\
34,000 \text { jobs. } \\
\text { The Broads: } \\
2,529 \text { jobs. } \\
\text { Exmoor: } \\
2000 \text { jobs. } \\
\text { Dartmoor NP: } \\
2000 \text { full-time jobs. } \\
\text { Government Scheme: } \\
\text { Grants created } 132 \text { new jobs; } \\
\text { contributed to the maintenance } \\
\text { of } 1,543 \text { jobs. }\end{array}$ \\
\hline $\begin{array}{l}\text { Cumulus Consultants } \\
\text { for Natural Parks } \\
\text { England (2013) Valuing } \\
\text { England's national Parks }\end{array}$ & $\begin{array}{l}\text { Assesses the contribution of NPs to economic } \\
\text { prosperity and well-being. Identifies future } \\
\text { opportunities for NPAs to support rural economies } \\
\text { in partnership with local communities, business } \\
\text { and local governments. }\end{array}$ & $\begin{array}{l}£ 10.4 \text { bn (Business } \\
\text { turnover) } \\
\text { GVA } £ 4.1-6.3 \text { bn } \\
(2012)\end{array}$ & $\begin{array}{l}157,000 \text { jobs. } \\
2 \% \text { lower than national average } \\
\text { Businesses }-14,000 \text { jobs. }\end{array}$ \\
\hline $\begin{array}{l}\text { Headwaters Economics } \\
\text { (2013) }\end{array}$ & $\begin{array}{l}\text { Studies conducted by Headwaters Economics. } \\
\text { No individual reports. }\end{array}$ & No mention & $\begin{array}{l}\text { NPs and recreation could produce } \\
\text { more than } 1,000 \text { jobs over time. }\end{array}$ \\
\hline $\begin{array}{l}\text { SCNP and APRS (2011) } \\
\text { Benefits of NPs }\end{array}$ & $\begin{array}{l}\text { Report to promote a strategy for developing } \\
\text { a comprehensive network of NPs across Scotland. } \\
\text { The study looks at the benefits to this strategy. }\end{array}$ & $\begin{array}{l}\text { Spin-off effects of } \\
\text { the impact of NPs - } \\
\text { income }\end{array}$ & $\begin{array}{l}\text { NPA's employ additional staff } \\
\text { both directly and indirectly. NP } \\
\text { status can increase tourism-related } \\
\text { employment and sustain businesses. }\end{array}$ \\
\hline $\begin{array}{l}\text { NP Service (2011) } \\
\text { Economic benefits to } \\
\text { local communities from } \\
\text { NP visitation }\end{array}$ & $\begin{array}{l}\text { Contribution of visitors, spending, and jobs from } \\
\text { the NP to the economy. Local economic impacts } \\
\text { estimated. (US) }\end{array}$ & $\begin{array}{l}\text { Visitor spending: } \\
\$ 9.34 \text { bn (labour } \\
\text { income) } \\
\$ 16.50 \text { bn (value } \\
\text { added) } \\
\\
\text { Local Impacts: } \\
\$ 4.58 \text { bn (labour } \\
\text { income) } \\
\$ 8.15 \text { bn (value added) }\end{array}$ & $\begin{array}{l}\text { Visitor spending: } \\
251,000 \text { jobs. } \\
\text { Local Impacts: } \\
162,400 \text { jobs. }\end{array}$ \\
\hline Lake District NP (2011) & $\begin{array}{l}\text { Tourism, the economy and the local community. } \\
\text { Addresses the benefits, challenges, and future of } \\
\text { tourism }\end{array}$ & $\begin{array}{l}£ 944 \mathrm{mn} \text { (income, } \\
\text { visitors spend) }\end{array}$ & 11,903 jobs (FTEs) \\
\hline $\begin{array}{l}\text { The Economics of } \\
\text { Ecosystems and } \\
\text { Biodiversity (TEEB 2009) }\end{array}$ & $\begin{array}{l}\text { TEEB draws together experience, knowledge and } \\
\text { expertise from all regions of the world in the fields } \\
\text { of science, economics and policy. Its aim is to guide } \\
\text { practical policy responses to the growing evidence } \\
\text { of the impacts of ongoing losses of biodiversity and } \\
\text { ecosystem services. }\end{array}$ & $\begin{array}{l}\text { NZ conservation: } \\
\text { US\$221 mn } \\
\text { Nature based } \\
\text { recreation in US: } \\
\text { \$122bn (just under } \\
1 \% \text { US GDP). }\end{array}$ & $\begin{array}{l}\text { NZ conservation: } \\
+1,814 \text { jobs. } \\
\text { Bolivia protected tourism: } \\
+20,000 \text { jobs. } \\
\text { SA Ecosystem restoration: + } 91 \text { jobs. } \\
\text { Europe: } \\
1 \text { out of } 6 \text { European jobs is } \\
\text { dependent on the environment. } \\
1 \text { out of } 40 \text { of those working in } \\
\text { Europe are directly employed in jobs } \\
\text { linked to the environment. }\end{array}$ \\
\hline $\begin{array}{l}\text { Getzner M (2009) } \\
\text { Economic and cultural } \\
\text { values related to } \\
\text { Protected areas }\end{array}$ & $\begin{array}{l}\text { The valuation of ecosystem services by the } \\
\text { examples of NPs in Poland and Slovakia that shows } \\
\text { that ecosystem services are of eminent importance } \\
\text { to the local, regional and national economies. }\end{array}$ & $\begin{array}{l}\text { Tatra NP: } \\
\text { ES worth EUR } \\
593-888 \mathrm{mn} \\
\text { Slovenský ráj NP: } \\
\text { EUR 155-342 mn }\end{array}$ & $\begin{array}{l}\text { Only mentions jobs of respondents, } \\
\text { not jobs created/sustained through } \\
\text { NPs. }\end{array}$ \\
\hline
\end{tabular}




\begin{tabular}{|c|c|c|c|}
\hline Reference & Comment & Revenue & Jobs \\
\hline $\begin{array}{l}\text { Font X, Cochrane J, } \\
\text { Tapper R (2004) } \\
\text { Pay per nature view }\end{array}$ & $\begin{array}{l}\text { The report describes the six survival essentials } \\
\text { for protected areas, and uses these as a context } \\
\text { for analysis of the role and potential of tourism } \\
\text { in protected areas. }\end{array}$ & $\begin{array}{l}\text { The economic activity } \\
\text { from travel and } \\
\text { tourism will generate } \\
\text { US\$5,490,900,000 } \\
\text { South Africa: } \\
\$ 35-53 \mathrm{mn} \text { (profits) }\end{array}$ & $\begin{array}{l}+73 \text { mn jobs directly } \\
3 x \text { this figure indirectly } \\
\text { South Africa: } \\
700-800 \text { new jobs over the next } \\
5 \text { years as a result of Nine tourism } \\
\text { concessions }\end{array}$ \\
\hline $\begin{array}{l}\text { Wilderness.net: } \\
\text { "Economic benefits } \\
\text { of wilderness" }\end{array}$ & $\begin{array}{l}\text { Discusses trade-offs between economic prosperity } \\
\text { and environmental protection. Looks at the } \\
\text { different benefits associated with wilderness areas. }\end{array}$ & $\begin{array}{l}\text { Outdoor recreation: } \\
\$ 80 \text { billion (taxes) } \\
\$ 646 \text { million } \\
\text { (spending) } \\
\text { Monetary value } \\
\text { of wilderness ES: } \\
\$ 2-3.4 \text { bn }\end{array}$ & $\begin{array}{l}\text { Outdoor recreation: } \\
6.1 \text { million jobs. }\end{array}$ \\
\hline $\begin{array}{l}\text { Holmes and Hecox } \\
\text { (2004) Does Wilderness } \\
\text { Impoverish Rural } \\
\text { Regions? }\end{array}$ & $\begin{array}{l}\text { Identifies a significant positive correlation between } \\
\text { the percent of land in designated wilderness and } \\
\text { population, income, and employment growth. }\end{array}$ & Nothing mentioned & Employment growth in \% terms \\
\hline
\end{tabular}




\section{Annex 4 - Ecotourism Industry Trends}

(Based on information gratefully received from Mr. Neil Birnie.)

The International Ecotourism Society (www.ecotourism.org) says the following on the status of the ecotourism sector:

- The wider sector of nature tourism is growing globally at $10-12 \%$ per annum.

- Since the 1990s, the sub-sector of ecotourism (which involves clear and positive linkages with the environment and benefits for local people) has been growing at a rate of $20-34 \%$ per year.

- Nature tourism is growing 3 times faster globally than the tourism industry as a whole (and therefore it could be said that ecotourism is growing at between 6 and 8 times the rate of normal tourism).

The International Ecotourism Society also makes the following general observations on the tourism sector as a whole:

- Resort tourism (sun and sand, ski resorts etc.) has now "matured as a market" and its growth is projected to remain flat. In contrast, "experiential" tourism which encompasses ecotourism, nature, heritage, cultural, and soft adventure tourism, as well as sub-sectors such as rural and community tourism - is among the sectors expected to grow most quickly over the next two decades.

- The United Nations Environment Programme (UNEP) and Conservation International have indicated that most tourism expansion is occurring in and around the world's remaining wild and natural areas.

- Analysts predict a growth in eco-resorts and hotels, and a boom in nature tourism - and suggest early converts to sustainable nature tourism will make market gains.

The International Ecotourism Society have also stated that sustainable tourism (which for the purposes of this report is believed to include all of ecotourism and most of nature tourism (excluding mechanised development such as ski resorts) could grow to $25 \%$ of the world's travel

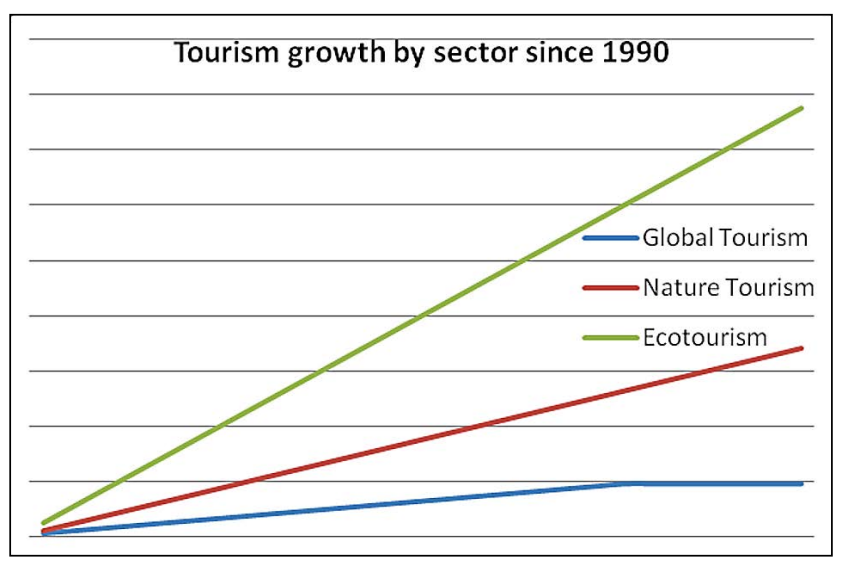

market within six years, taking the value of the sector to US\$474 billion per year.

According to the UN's World Tourism Organisation (www.unwto.org), ecotourism and nature based tourism are among the fastest growing market segments worldwide. Research has shown that $8 \%$ of all trips currently sold worldwide can be described as ecotourism, with a potential grow to $15 \%$.

The growth in the ecotourism sector is also increasingly recognised beyond the tourism industry itself. Economy Watch (www.economywatch.com/world -industries) recently stated that:

"The ecotourism industry is fast catching up with other flourishing industries of the world. Ecotourism is growing by leaps and bounds. The ecotourism market makes up 6\% of the GDP all over the world. Ecotourism refers to the practice in which the place one visits is not harmed in any way, thereby maintaining the natural equilibrium of the place. This includes aspects related to maintaining the flora as well as the fauna of the place. Every effort is made to keep the place in its original form."

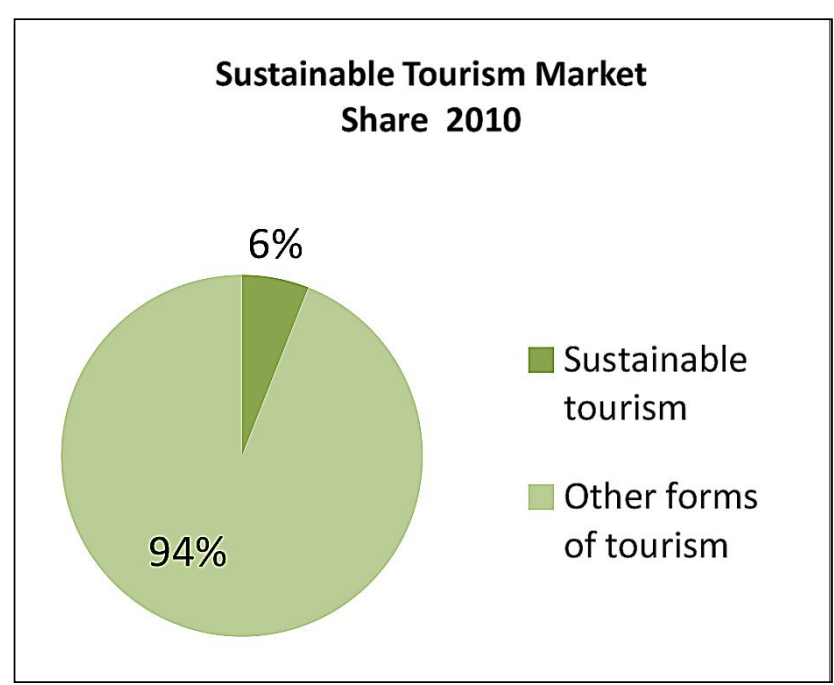

Sustainable Tourism Market Share 2020

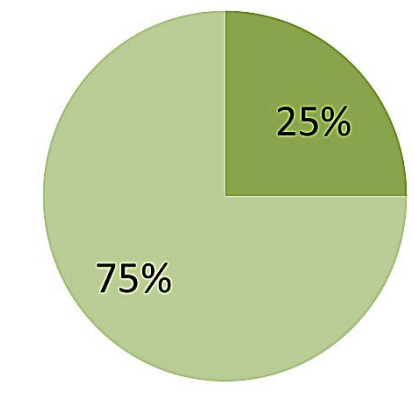

Sustainable tourism

Other forms of tourism 